\title{
darkcloud/blog
}

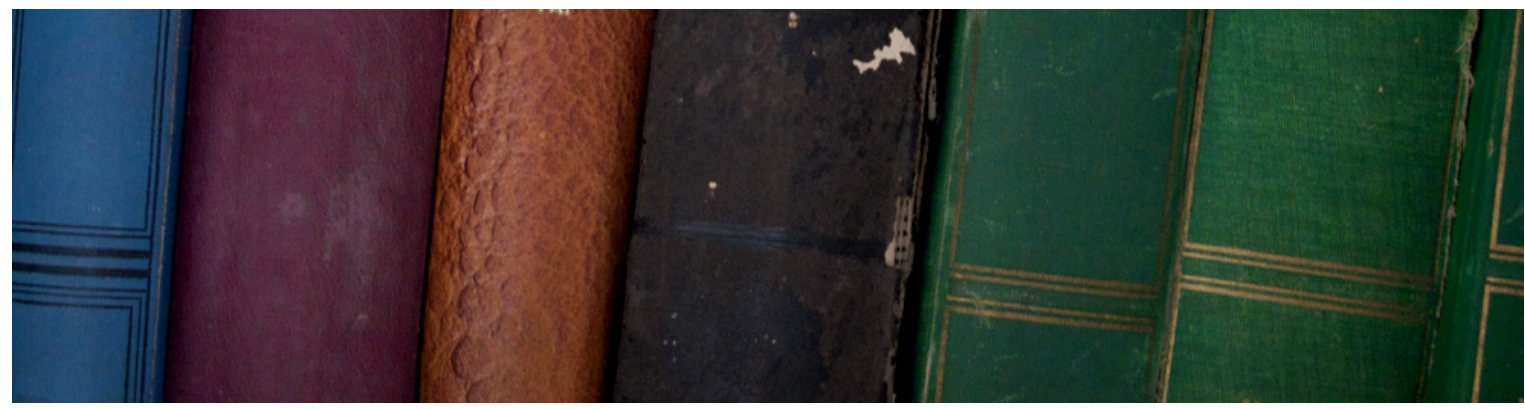

JANUARY 30, 2017 • 6:35 AM

\section{morning has broken}

L sees a beautiful path i wish i did jasmine is hell. abandon all modesty and freedom. abandon hope. use up your love, your friends. distance from your sweetheart, from your baby dog. lose food and drink. oh to drink again. draughts and draughts of water. oh i so miss that.

so last post. i thought i had something to say. but really, i don't. just the same things. bad worlds. goodbye cruel worlds cliches. love to all. i miss everything. and all of it. and all of you.

JANUARY 20, 2017 • 4:33 PM

\section{end of days}

i can't fathom the trump inaugural. but there is also too much of a fixation on him when the problem is so much deeper and extends to the entire corrupt republican establishment .

and yet i have to ask myself how much is left of me to care about this. feeling so much worse. but on and on it goes. no more energy for things. goodbyes. good wishes. none left in me. 
JANUARY 6, 2017 · 7:09 AM

\section{Re Nancy Fraser's article about the death of progressive neoliberalism}

re nancy eraser's article: >

https://www.dissentmagazine.org/online_articles/progress ive-neoliberalism-reactionary-populism-nancy-fraser

Some good points I think. But, also wrong in parts. For example, she doesn't acknowledge that Clinton did win the vote, or that clintons platformwas $75 \%$ sanders, which means it was in itself a significant break with BILL clintonism, Hilary also addressed the rust belt and jobs. But the media and republican elites and FBI and putin were allied profoundly against her per se as they always have been. Hilary is not bill. There is no 'clintonism'. And Fraser over emphasised a rational self interest motive fortrump supporters, which is not persuasive to me. That has much more to do with projective standing in for entitlement. Trump got votes because he is an entitled privileged bully who has reinstated the speakability of white entitlement. And is part of the mediatised reality culture which is phantasmatically more real than what is real.

My opinion anyway.

$X x x d$

\section{[from note to B who sent me the link]}

to this i'd add that the rust belt is not the only casualty of progressive neoliberalism - there is also, among many other casualties, the wanton destruction of education from state schools to universities in general (marketisation, demonisation of teachers, adjunctisation), to facts and logic and evidence; to democratic structures

'(gerrymandering, destruction of citizenship, privatised prisons and corrupt, racist policing), demonisation and destruction of social/health safety nets, re-rise of authoritarianism. none of these issues is intrinsically trump territory. many casualties of progressive neoliberalism support/ardently desire an alternative progressivism. 


\section{goodbye}

\section{goodbye}

I think of you

I remember love

It burned inside my heart

And rushed along my skin

I held it there

the dream

of you

it was

oh love was fire

I was alive

2008

\section{goodbye (Variation)}

when I /

spoke

finally /

my voice stunned

before the end of this day

grey /

winds

struck ice /

we shivered

this estrangement 
how /
could you

shrunken /

bone cold

know yourself

or my /

fury

for what I called it /

love

what we called it

when /

we spoke

intimately /

my jaw shook

with the effort

stone /

barriers

caught my throat /

we had

no language for that 
how /
could it
happen /
that terror

could/

rock our flesh

like this

crawling /

stunned goodbye

from our lips?

1991

neither of these poems were about me . until now. when they are. unimaginable twist of fate. and what is lost is me. have to relearn to type again. hands not working now. stylus hard on a laptop. haven't figured it out.

JANUARY 1, $2017 \cdot$ 10:02 AM

\section{trapped in the new year}

anticipating calamities. israel/palestine, brexit, trump, syria, refugees everywhere crashing into intolerance and cruelty. the world $k$ and her peers will have to confront, left to them to make better. a sorry world. and here i still am, trapped in a chair, barely moving hands inexorably contorting to their own calamity. nothing $i$ can do now. all the things i wanted to be throughout my life were active. poet, scholar, activist, actor, director, editor, artist, designer. maker of things. now ending like this. except its not ending. why not? it needs to end. i need to end. 
biopolitics. irony of its totalising reality. not capillary power. it coalesces instead. a central proscription. you will not be enabled to a final fear free, pain free end. this is what they see as 'reasonable limits'. i hope everyone who takes that position suffers as i do. i feel vindictive about this. let them suffer what they impose, thinking this is moral, they are elevated. entitled. be grateful. doled out in antagonised defences 'but i am here to help'. yes, help yourself. protect your comfort. as you do what most any person takes for granted, standing up, leaving the room, picking something up. drinking their drink. you have no idea. and you are hateful and selfish. i say so.

does this apply to the world? yes. that too.

DECEMBER 31, 2016 $\cdot$ 11:05 AM

\section{blow you off}

can't leave fast enough. close down. get away. this is a trap and free people need to be free. even if plan fell through. that door is escape. dash. get away.

meanwhile is hidden for now. can pretend it away. resentments don't matter from a distance. can face away. not looking.

lola is asleep with smile. not like yesterday when she was slumped morose in her bed all day. now just me who is morose. difficult. hateful. get away from her. get away.

DECEMBER 28, $2016 \cdot 11: 43$ AM

\section{postscript}

$i$ thought i might be done with this. left hand folded over and crushed. no longer working. now right hand going. need to go to bed every hour. what more to say. am sick to my stomach all the time and sitting up is an ordeal. but then o is lying down. does anyone really need to hear this chronicle. do i really need to write it. letters from friends. hard to write back now. what to say. no stamina for it. alienated from lola. nothing left for her and she has migrated to g. i am jealous. but how not. 
watching big bang theory season 10. easy watching. interruptible without losing the plot. guess my mind is going from feeling so fatigued.

DECEMBER 24, $2016 \cdot 1: 48$ PM

\section{seasons}

watching youtube videos. things i want still to do. i still want things. i still miss things. everything is much harder. need oxygen so my heart doesn't have to work so hard. watch people with wild animals. always wanted to do that. watching comedy. kate mackinnon. watching peoples hands. when i dream, mine are still like that.

dreams about food. sometimes bad, others just strange. today wanted to eat.crushed ice to drink better than popsicles.

i miss fashion think about clothes i won't get to wear. and things i won't get to build. and home in los angeles. i didn't guess that i would be lost in england. always thought it would be the other way around. recurring nightmare i had for years. lost in familiar places. like pico boulevard. but everything i built gone and i forgot where i was supposed to go. or the beach. where no one was there and i couldn't tell if $i$ was north or south.

it is christmas time. i always liked christmas. lights and decorating the tree. presents. nice food.

if $i$ was well $i$ would bake a cheesecake. and cookies for the neighbours. and i'd figure out something for a nice dinner. and $i$ would be able to eat it all. and when i'd go to bed it would be soft and my muscles would relax, instead of stiffening up and hurting. i'd find something nice to wear and $\mathrm{g}$ and i could have a party. we could drive to costco and get a cake that i like. we could put out starters and $i$ could make lasagna or chicken skewers and rice. we could invite our neighbours and friends.

then i could fly home. and feel the sun.

DECEMBER 24, 2016 · 12:03 PM

\section{addendum 2}




\section{from an article in the guardian today}

I now recognise that the whole project of sharing our Christmas was flawed, and it taught me a salutary lesson. It taught me something about what could be termed benefaction. Caring can lead us to expect the objects of our care to be gracious in their receipt of our largesse, to accept unreservedly our support; essentially, to know their place.

And when they don't, when the victim refuses to submit to their victimhood, when they insist instead on retaining ownership, they challenge our charity and we take offence. What I learned, that shameful Christmas, is that charity, care, whatever you call it, is essentially a two-way process, in which the recipients may be victims to us, but they are desperately seeking to restore the selfhood that the slings and arrows of outrageous fortune have eroded.

That is their right and, while we are distributing the Ferrero Rocher, it behoves us to pay attention. There's a lesson for the $1 \%$ in there somewhere."

https://www.theguardian.com/commentisfree/2016/dec/24/lonelyold-lady-christmas-lesson-charity

\section{my comments}

AND A LESSON FOR THE HOSPICE CHARITY MOVEMENT TOO. ITS WHY K FINDS ME SO OBJECTIONABLE AND BULLDOZES THROUGH MY EXPRESSED INTENT TO KEEP OWNERSHIP OF MY LIFE AS AGAINST HER COMFORT ZONE. THEY GET OFFENDED AT MY INTERROGATION OF THEIR ILLOGICS. AND ARE FRUSTRATED BY MY FIGHTING TO KEEP MYSELF IN MY OWN TERMS INSTEAD OF GRATEFULLY SUBMITTING AS A COMPLIANT PATIENT. THEY WANT TO FEEL GOOD ABOUT WHAT THEY ARE DOING. AND I MAKE THAT DIFFICULT.

DECEMBER 23, 2016 · 6:14 PM

\section{addendum}

$\mathrm{d}$ thought my last post was harsh. yes. she is right. $\mathrm{i}$ was harsh. palliative care is doing their best within constraints they are bound by. maybe believe in too. they can't stop me being a hostage. if $i$ want to move, i have to ask and then wait each time. not anyones fault. just 
how it is. they say we can give you drugs within reasonable limits. $\mathrm{i}$ ask, what defines reasonable? it upsets them. $\mathrm{C}$ was equivocal. maybe how she feels. maybe constraints of her position. i got angry. festering with it. but not necessarily at anyone. just angry. So am sorry to have been harsh.

the problem is i don't want to die. but am anyway. i want to stop it. I'm fighting unconsciousness. i wont have peace or acceptance. there are bad ways to die. this is one of them. i resent dying. i resent having my day to day everything in other peoples hands. people like me make demands. we don't want to wait because waiting is itself a galling loss of selfhood. you fucking wait i want to say. but know that this is unfair and ugly. but also the truth. who wants to loose all the minutia that add up to autonomy. self respect. self definition.

so in a way I'm not sorry. and am sorry about that.

DECEMBER 23, 2016 • 1:19 PM

\section{self sovereignty 2}

likely my last entry. can't be sure. but want to get this down. thinking about it since palliative doctor, C's visit. i asked for propofol sedation as this drug i know and it kicks you out totally and without thoughts. she said it was illegal in uk. this is illogical. i didn't say kill me with it, even though i think they should just sedate me with a drug i can tolerate that won't leave me looking sedated to outside world, buy in terror in my head.

$\mathrm{i}$ am angry beyond measure. $\mathrm{C}$ said well the law is trying to protect people from feeling pressure to die. Well fuck that because it is fine with forcing people to live in suffering. why is that pressure ok? and to the so called 'disability rights' activists who oppose assisted dying. i want to say to you that you are all selfish assholes. This is not about you. its about people like me who are in fact dying. everything is not about you. this is not a euthanasia issue, $\mathrm{i}$ am dying anyway. it is no more euthanasia that abortion. this is my body and my rights over it. you claim this for yourselves but deny it to others to serve your paranoia and issues that are not germane to this situation. get over your damned selves. you aren't entitled to other peoples lives. like the anti abortion lot, you are moralising, selfish people who think the world should be defined by you. if you don't want assisted dying 
for yourself. then don't ask for it. you stupid awful people. i suspect i am not the only person like me hates your guts and hopes you are cursed to your own stupid politics. $\mathrm{i}$ hope somehow this message gets to you. you are bad people. and someone is telling you this to your faces. maybe you could think about what i am saying. though i doubt you will. $i$ hate you even more than the vacuous oligarchs and religious types who also oppose assisted dying because of equally specious politics. it won't affect them. or they think people should be forced to live to spare them grieving or facing that people die (I'm speaking to you giles fraser - whose writing i mostly like - but you are criminally wrong on this issue). but the disability rights people $-\mathrm{i}$ support your rights for self determination. so the lack of reciprocity enrages me.

so my last words are not nice. they are angry.

DECEMBER 20, 2016 • 1:46 PM

\section{thank you, too late}

I have many thank yous. But too late now. Cant get the list straight. Headache wracking my head. just want to sleep. Feeling bad about this. many people to thank and say last words to. But too late. Waited too long.

love to $\mathrm{g}$.

DECEMBER 19, 2016 · 1:12 PM

\section{could we start again, please}

GP just left. not clear if i have a bowel obstruction. if so, not clear what to do. very bad news if so. She is calling palliative care to discuss with them. All this talk.

$\mathrm{J}$ and $\mathrm{C}$ moving today. very sad day.

Watching Jesus Christ Superstar again. trying to pass the time. inspired musical from choreography to multiethnic casting, to musical arrangement and cinematography. Andrew Lloyd Webbers best work. interesting subtextual love stories visualised among apostles, between judas and jesus. hippy aesthetic. 'now we are 
decided' a powerful comment on how power struggles play out.

DECEMBER 19, $2016 \cdot$ 8:34 AM

\section{goodbye}

My mom and brother had to leave this morning and I feel so awful about it i am beside myself. i don't want them to go. i feel devastated to say goodbye.

everything is so awful but it doesn't end. i want it to end. now some kind of bowel obstruction. painful. makes me sick. cough much worse. fear of smothering. no world left. can't think about the world. stopped caring. am afraid to take it into my hands. don't know how. afraid to make it worse. wish i could be in induced coma with propofol, then finished off. fast. without more pain. no more fear. no more gasping for air in panic. just done.

L sent this link. i guess i still care about some things.

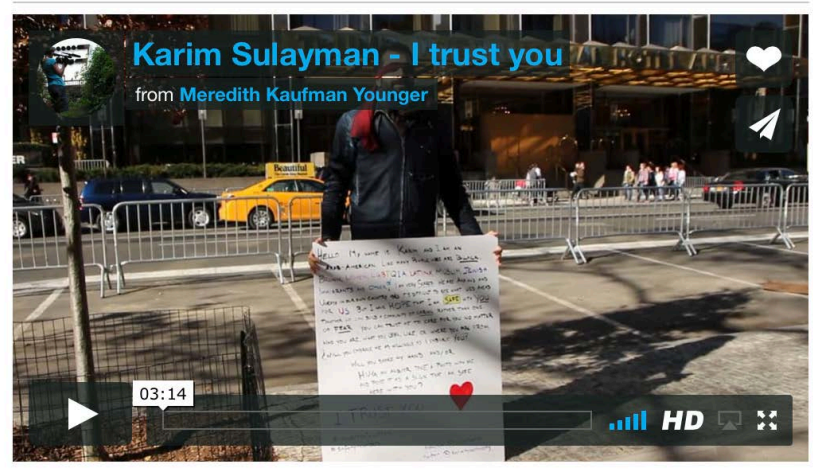

\section{https://player.vimeo.com/video/193125533}

Meredith Kaufman Younger

DECEMBER 16, 2016 • 4:02 PM

\section{harder to manage}

it is getting more difficult to manage, even the marginal space. Visit today from $\mathrm{N}$, which was very nice, though i was not able to talk very well. She brought fragrant flowers which look nice on the mantle. A 
wrote. She is sorry more can't be done. I don't envy her her job. Would be hard to treat and then lose patients. Must be hard to protect yourself.

Hair appointment in an hour. Cant really manage any more. but didn't want my hair to be lost too.

DECEMBER 16, $2016 \cdot 8: 10$ AM

\section{much worse}

am much worse. hard to choose what is most problematic. headache. destroyed painful hands, humerus pain which might be a fracture, heart problems, cough and choking. all terrible. nothing to be done.

DECEMBER 14, $2016 \cdot 10: 29$ AM

\section{visit}

C came over for visit today. and my mom and brother arrived. Difficult now to hold my own. G trying to stop ame from isolating myself. Thinking about the etiquette of visiting. A to and fro movement. A give and take. What happens when the transaction is halved? There is some fundamental breach involved. Something against the normal social contract. These are small estranging moments, that remove you from context and social ties. It is not that $i$ would expect anything different of others. And no one is asking anything of me at the moment. But that is part of the dislocation.

\section{DECEMBER 13, 2016 · 9:58 AM}

\section{unsong}

I wrote a poem many years ago. It started that way: this is an unsong/ a trance/ an undance... And so it is. Just that. I am suddenly much more tired. And I have a headache that won't go away. About a week now. I might know why. I hope it just makes me sleep. Its hard to breath. Its hard to hobble down the hall to the bathroom. Its hard to sit or stand or lie down. 
I am watching madonnas rebel heart tour on the iPad. How they all move. L sent pictures of a recent party. Friends that look well.

DECEMBER 12, 2016 • 7:04 AM

\section{what is logical}

I found myself thinking last night about the original Star Trek. I'm not sure I can reproduce it here. It's probably stale now. But was thinking about this laterally from the notion that we are now in a 'post truth' era or consensus. I haven't watched the original since I was in elementary school But I did love the show and was entirely persuaded by the moral compass provided by the character of Spock, as against the selfish and rash adventurism of Captain Kirk and the reactive judgementality of Dr Bones. As I recall it, the other characters were not positioned to make global evaluative judgements on ethics, action or affect. What I liked about Spock was his 'natural' recourse to logic. As half human, it was thus only a superficial conceit that this was not also or not possibly a human capacity as well. Spock provided the ego ideal of justice in a time when faith in rational argument was the dominant metier of politics, of futurity, and of understandings of the human condition.

In my second year of University, I took a philosophy course called Principles of Critical Reasoning, which focused on the constitution of logical argument and the ability to parse logical fallacies. It was one of my favourite classes, notwithstanding the myriad cartoons I drew in class of the professor, Bob (I don't recall his last name). Drawings of Bobcats, Bobsleds, Bobsicles and so on. Drawing as it were, on his bearded post-hippy long haired countenance. I believed in this class. And I learned from it, worked hard on assignments, found it filtering into my day to day life.

So what can it mean to be 'post-logic' and 'post-truth'. I drew on this question in a way in my gene book, considering the truthiness of genes. But i don't think I assimilated my own observations about projection and persuasion sufficiently, such that Brexit and Trump and authoritarianism in general could make any sense at all. To me these are unnatural. Against my formative understanding of discourse, of reality, even of attachment and repudiation. I love the capacity for logic. My own ego ideal. That one can build a good fabric 
out of reasoned compassion and empathy.

DECEMBER 11, $2016 \cdot$ 8:24 AM

\section{trigger warning}

A term I actually dislike profoundly. As I read Jack Halberstam's two blog posts on the subject, bad memories from the 80s and early 90 s surface. Writing to Spare Rib (in the only thing they ever published of mine) to note that the supposed anti-censorship faction of the 'sex wars' debates were spending a great deal of verbiage and scorn telling those who disagreed with them to shut the fuck up. I was sick of it. the one sided contemptuous monologues and exhortations. The arrogance of silencing others because you think their words are ugly stupid barbs but yours are benign, or the truth, or not, in any case, accountable. But words matter. And in so many respects, are matter. And everybody gets to have their say in a conversation.

So I use the term here, though that wasn't my intent when I opened my laptop to write. It is because I have a headache. I have for several days. I think it is a sinus headache or a stress headache. But what do I know. It could be much worse. So a warning. What is coming will be traumatic. You won't want to engage. You'd rather be reading something else. Protect your sensibilities.

From my current vantage point, $\mathrm{i}$ have no patience for the trigger theory. A mechanistic absurdity. A pathetic whine. I also want to say, grow up, your desire for safety doesn't trump others lives who don't have that. Your pain is not the only pain. Your desire to be cushioned against ideas, knowledge, hard questions - why don't you think about how selfish that can be, how against the spirit of democracy, how undermining of any meaningful education.

So here is a trigger warning for you who feel that way. I have ugly and unpleasant thoughts today about your claims. I don't really care, today, about your safe space as against people like me. You might want to switch this off. Protect yourself. Some devastations can't be pretended away, unless you turn your head forcefully. Lock yourself away, but do so by imprisoning others. What if your space was achieved by switching off and marginalising the lives of others. Trigger warning. I am angry today. Because i woke up at 4 am like I do 
every night, choking. I was dreaming something I don't remember. Then choking and aspirating my own saliva. Now I'm sat on this air cushion that feels like concrete against my bones, feeling exhausted. Pain in my hands, which are degenerating further and at pace. Pain all over. All the time. I'm angry. I'm aggrieved. Find somebody I can sue for safe space why don't you.

Yes, I am addressing a straw 'you' here. i don't care.

\section{[from letter to $R$ ]}

Hi R,

Glad you're working out best visit dates with G. Will be good to see you and $J$.

The driving out of conversation in the wake of factionalism is disturbing, though I think probably ascribes to all social movements and many kinds of social interactional relashionship. I noted this in my blog about the question, but reading JH's two pieces on trigger warnings recalled a number of quite unpleasant memories for me from the late 80 s and early 90 s during the infertility debates and the so called 'sex war' debates. A lot of obtuse nastiness and decisive resistance to listening and dealing with views people didn't like. It was alienating and depressing. I have some of the same resistances myself of course. I feel disquieted and alienated by the language of cis as it seems to negate everything I fought against VIS a VIS gender politics my whole life, this resolution into an unpleasant binary that makes no sense to me at all. I feel frustrated at the idea that talking about female reproductive organs is intrinsically 'trans phobic'. And the whole TERF wars thing seems as straw as it gets to me. Both seem worse than absurd to me. Like talking about ambulatory bodies is intrinsically a repudiation of bodies like mine. That makes no sense to me either. At times I encounter such positions, I feel just as resistant. I feel that about trump voters. I know they have their reasons and are not an undifferentiated mass. But I am not sure I care. So I don't mean to impugn this impulse in others when I have that in me as well.

In my best moments, I believe in conversation. But it's hard to keep to that sometimes, isn't it. And so, my own stridencies emerge too.

Anyway, you make a number of compelling points...

\section{[from an email I wrote conversation with J]}


...It's true what you say about how anger gets mis-placed onto what is convenient and available. I don't have a lot of patience for it. And I suspect having longer memories of internecine conflicts and gratuitous nastiness from earlier moments of activism makes me more inclined to frustration with the whole safe space appropriation. Safe space was supposed to create an opening for speech otherwise marginalised or proscribed, not to protect us from thought and critique and self reflexivity...

DECEMBER 10, $2016 \cdot 9: 19$ AM

\section{last rites}

What are these for, last rites? Rituals of confrontation? That stylise what is real into just enough regimentation and surreality that you can accept it? Dying people are minor characters in this endeavour. Devices for the traumas and resistances and redemption of the other characters. Like Diane Keaton's mother figure in The Family Stone. A condition of the lives of others. Their loss and tragedy and the way life went on. I am re-reading Marge Piercy's Body of Glass. Another minor character caught my attention. Gadi's mother, dying of a mutated virus that is melting her bones, dying in a haze of drugs and agony. We read of her marginally, Gadi's tragedy, his pathos, the antiredemption of Avram, post-modern maharal, who would build a conscious weapon in his cyborg golem son. In my many previous readings, I did not take much note of Sara, this minor character. Until now, when I have become her. I resent any talk over my head as if I am not still here. But really, I am not still here for the purpose of this kind of narrative. Just a tautological remnant, an artefact of plot, but not a mainstay character. So last rites are not for me. Except this one I guess. I invented this to serve myself, wind down my own story.

DECEMBER 9, $2016 \cdot$ 10:23 AM

\section{shouting into the void}

Overhearing $\mathrm{G}$ shouting on the phone at the NHS because I still haven't had my choking evaluated and its going toward a month since the urgent referral from the GP. He managed to get them to hear him but the appointment is not until next thursday. I can't militate on my 
own behalf anymore. the alternative is admission to the hospital, which is a ridiculous use of resources and I don't want to do in any case. A was also clear that she thought the hospital would be a very bad place for me and wants to try to keep me out of it. This is what a starved health service does and doesn't do.

$\mathrm{C}$ and several others wrote with intent to visit. I am in such terrible shape. I don't know how I can hold up my end. I can no longer talk. I am tired. I make terrible sounds. I look dreadful. I know its not supposed to matter. But I am consumed with this.

i am sleeping more during the day. just short snatches as i keep choking but id sleep for longer if $i$ could. maybe a sign that this will all be over soon. I still feel my mind alive and with little compromise, even as everything else of value to me is twisting out of shape into painful loss. My hands are in a shocking state. we are buying a blender to see if we can make things I can swallow. but i sense it is too late to do much good.

DECEMBER 8, $2016 \cdot 9: 43 \mathrm{AM}$

\section{normotic introjection, further thoughts}

S asks if secrecy is a normotic phantasy too. Yes, I think so. Tied up as it is, in the technologies of denial, subterfuge, dominant governmentalities. But is privacy too. And self sovereignty. M raised this with me when we were writing the introduction to the special issue. The fallacies of individuation, sovereign selfhood apart from others, a denial of the interdependencies of bodies and lives that are in fact the human condition. Who is an island really? And yet. I think of the ways in which secrecy - call it discretion, call it hiding, call it dim lighting my own lights - has dominated much of my own life. The sense of obligation that has driven it. The embarrassments in its wake. $\mathrm{S}$ is right that shame and guilt are cruddy, cruel oppressors. But so they are embedded in the fabric of so much.

I'm not sure where it comes from. The need to be fastidious, the disgust and despair at the sullying of this in my own house, in and of 
my own body. Not the hospital or the doctors. I think it is something in me and not something I expect of others.

When I first got sick, at the end of the treatment cycle of 2008, I was assailed with feelings I can only describe as venom. They were deep and they were directed at me. Ive struggled with feelings like that before and after, but nothing like what happened then. Where did it come from? I don't feel it now. Just the embarrassment of not being able to talk, or wash without assistance, of having to give up the quietude and cleanliness of body that I had before. There is no capacity to hide, dependent as I now am. It breaks boundaries I wanted to keep intact. It is not something I want witnessed. And it can't go unremarked, because it has marked everything I do now. Hard won, I manage sometimes to reflect on things here or in letters. But my hands are beyond repair and who suffers this? My cough is a dreadful hacking raking sound that scares Lola and disgusts me as I choke on nearly everything, including the normal effluences of my own body. I am forced to spit it out, uncouth and crude, into tissues I go through in bucketloads. My legs look like twigs. My left arm too. My hair is a rats nest I can’t do anything about. I hesitate to ask for help. Most people don't know how to do my hair. It is hard to brush out the knots, hard to pull it away into a plait. People who have tried are tentative and overwhelmed by it.

Maybe its good that i am starting not to care. Though G says not. And I spent the morning crying as I read the letters from $\mathrm{S}$ and L. So I guess I do care and just wish I didn't.

\section{[letter from S]}

Hi Deborah,

Maybe dignity is one of those things that appears only when it disappears. That would make it a negative experience. But there can be dignity, I think, in the negative. A cheap deconstructive turn might suggest that the negative is dignity's condition, if not its limit concept. But theory feels like a betrayal in these moments, abstract to the point of being callous.

One word you use is privacy, and I think this is rather profound. Privacy is not secrecy. We all know there is no secret to leaky bodies, to what is considered dirty, or spattered, or broken, and so forth. These things are not secret, but we might wish them to be private. Even symbolically private, respected, a small gesture, a touch. 
Withdrawal I understand, but this feels like secreting oneself too. I'm not sure if it's privacy. Maybe it is. Care of the self or selfsovereignty? The open secret that sometimes we cannot care for ourselves, that this is the human condition, that self-sovereignty has limits, that our sovereignty relies on others but that this does not necessarily make us any less dignified or sovereign? Secrecy is a veil of ignorance that says that we know but pretend not to know because we would rather it not be so. Is secrecy a normotic phantasy? And would privacy be something else? And dignity too? $G$ is right: you have nothing to be embarrassed about. I hate this word, embarrassed. It is shame, maybe even guilt, and secretes you away as untouchable and alone in your responsibility. This feeling is a true indignity, and those who make you feel this way, doctors or NHS staff, they are cruel and cursed.

Sending love xox

Hi S,

I took the liberty of trying to think through your points on my blog. They are good questions. What is privacy vis secrecy. What are their normotic dimensions. What is embarrassment and where does it come from.

I can't say I've come to any better understanding. It may be wrong to feel undignified or embarrassed, but these I do feel. it may be self defeating to try to hide away, but that is what I'm doing. Ifeel the crudity of my condition keenly. I feel disgust at it. I feel angry. And I just want it to be done. I am afraid of suffering more or I'd figure out how to take this into my own control. But there is no easy way to die. I hear of people who just fade away, or or gone quickly. That is not in the cards for me. Some people are tortured to death, at the agency of other human beings. I guess that is worse. But not much comfort in thinking so. It would be better if I was a dog or a horse. Someone would stop this.

I am sorry for saying such things. I know it is not nice to say and where does it leave the hearer? I do appreciate your letters. They engage me in the best of ways. They make me think. I've been missing thinking.

Sending love and hugs,

$X x x d$ 
DECEMBER 6, 2016 • 8:43 AM

\section{what is dignity}

I am thinking about this question: what is dignity? Is it privacy? A boundary that you agentfully assert, an adult thing, that keeps things quiet that should be kept quiet. Is it an intact body, no leakages, or untended hair, washed clean, no effluvia. Is it keeping your own counsel out of self respect, and respect for others. Is it self sufficiency, taking care of your own, cleaning up after yourself. Taking responsibility. Is it stoicism and fortitude in the face of the unbearable. Is it something clean instead of dirty, concealed instead of splattered indiscriminately, is it discernment and pride and self actualisation.

I can't answer this question any more. I can't tell what is worst because all of it is so terrible. But loss of dignity is part of it. My inclination is to withdraw, so no one sees me this way. G disagrees. He thinks I shouldn't cut people off. I find embarrassment difficult. He doesn't see that I have anything to be embarrassed about. But there it is. I am embarrassed by the bag of bones I have become, by the way I choke on my own saliva and that racking awful cough that gets provoked when I do. I am embarrassed by the difficulty talking. By the interminable decline that doesn't just end as it should. I think $\mathrm{G}$ is coming to see that it needs to end.

DECEMBER 3, $2016 \cdot$ 2:14 PM

\section{afterthought}

$\mathrm{R}$ raised a good point re my post from yesterday. Like Jonestown, there was is a promise in Scientology that I can, in fact, apprehendthe sense of making a better world and a better self, as some of the interviewees said. But Im looking for a way into the Trump moment, or the Mussolini's, or Brexit, the Golden Dawn. These have something cult like about them but are they analogous? Lime many, I am looking for purchase on this disaster. As if makes a difference to do so. I'd like to think it does. But I'm not sure about that either.

So the documentary left me short. It explained, but it didn't help. 


\section{Hi Deborah,}

I saw your blog post about Going Clear.

I was wondering if you'd come across Kate Bornstein's A Queer and Pleasant Danger: The True Story of a Nice Jewish Boy Who Joins the Church of Scientology and Leaves Twelve Years Later to Become the Lovely Lady She is Today? (such a good title I had to reproduce it in full). I think it's available as an ebook.

In it, Bornstein writes in depth about how the persuasion worked for her, why she found Scientology appealing and ended up being drawn deeply in even though (to the external world) it would appear that she was at least relatively well-adjusted in her life. She also writes a bit about what happens next. I'm not sure how much Bornstein's story offers an insight into the journeys of others entering (and leaving) cults due to the very person nature of the narrative and its relation to her struggles with gender, but I do think you might find it of interest. I found it it a really good and very revealing read.

Thanks $R$.

I think I have read about bornstein's book - a good review. I guess part of the problem with the film is that it didn't address the persuasion for the people it interviewed. Nor really put their lives in wider context. And of course some of the people who escaped were brought in as children or born into it. There is a very good frontline documentary about Jonestown which does look at these questions and also the subject is covered quite sensitively in Tales of the City in one of the later books...

DECEMBER 2, 2016 • 6:44 PM

\section{all lost. And I wonder}

I just lost everything i was writing from today and I feel devastated. $\mathrm{i}$ did something to the screen and it swiped into oblivion and I can't get it back. I pressed save as i was going but it still disappeared. I depend on technology but I hate it. Its been too many hours so I can't reconstruct it. I hate this format because I don't understand how it works and I hate this machine because it does things I don't understand. My folded over fingers accidentally press or move 
something and I can't get it back.

I was trying to write about Going Clear, the documentary about Scientology that I watched today. I said that I thought it was a weak film, with nothing to offer that wasn't already in the public domain, or already stated much more powerfully by Paul Haggis in his widely circulated article. I wondered what it is about charismatic authoritarian charlatans, that persuades people? I understand being trapped, held hostage, oppressed to the disappearance of imagination. But I don't understand the persuasion. To choose this, when you have the means, the capital, the choice, not to. And I wonder, because the film did not say, how people who left managed to start over, pick up the pieces, move on. Some had major roles in the film industry that they could rely on, but what about then others?

$M$ visited today. I was worried because it is so hard to interact now as my voice is gone and i feel so sick all the time. But it was a nice visit and I'm grateful that she wanted to come. And lola was delighted. The fine discernments of dogs.

DECEMBER 1, 2016 · 9:49 AM

\section{why narcissism - some wandering thoughts}

$\mathrm{S}$ has questioned me about my invocations of narcissism. And I think he is right. What do I mean? As he points out there are multiple types of narcissism. Not just the pre-oedipal Trumpist 'his majesty the baby', who extrapolates the world from himself and arrogates it to himself as a matter of right, What he wants always already belongs to him. But D and I had extensive conversations about Kohut's theory of healthy, necessary narcissism. We considered it in relation to our understanding of the psychodynamics of the Bourne films. But it also applies beyond that. The ability to care for oneself, to contain one's own contradictions, the capacity for self love and self respect. The capacity to meet the other as an equal.

And maybe a good narcissism is the ability to stand up for your 
dignity, to assert your agency, the desire and capacity to learn. What comes to mind as I write this is a memory of Lola as a puppy. She did not like fetching things. She found it pointless and boring, preferring to roughhouse with me according to rules I have never understood. But I did have these miniature nerf balls all over the floor and would try to get her to play with me with these anyway. One day when I was working, facing the computer, I heard a commotion going on behind me. I turned to find Lola throwing a ball and looking thrilled with herself. It seemed to me that she had suddenly discovered her own agency, that she could act on the world and have an impact. For several weeks, she engaged in throwing nerf balls around, eventually extending that to throwing her little stuffed toys at me or across the room, when she wanted something from me. Whether dogs have a sense of dignity or not, I don't know. But for me there was dignity and agentful self love in Lola's exercise. She does something akin to this now - realising that I'm not well enough to play as we used to, she stamps her feet at me and challenges me to mini duels in bed. I've come to realise its not instrumental as I'd first thought. She isn't demanding treats. She likes to make me laugh.

So what do I mean when I continually attribute narcissism to the exercise of this blog? Do I really think it is self serving to want to leave a mark in the world, or to externalise my inner thoughts, or to reflect on my situation, sometimes to the exclusion of other things? Am I worried about the appearance of complacency, or self-involvement to no end but itself? I agree when S points out, my assertions to the NHS are not self serving, though they are a plea, and at times a militancy, on my own behalf. I don't think it is only me who should get decent treatment. So what is narcissistic about all of this? I don't know. Yet I worry about it. Sometimes feel embarrassed, or want to distance myself. I do feel mawkish and angry and sorry for myself. Is that selfish? I don't think I'd say it was if it was someone else. I tell G I am sorry for turning out to be such a bad bargain. And he asks, is that what you'd feel about me if the situation was reversed? No I wouldn't.

Many years ago, when $\mathrm{C}$ was the bane of the Department, among a number of narcissistic incursions into our intimate, interpersonal.political dynamics, I was able to contain myself by reading and rereading an essay I found online, about how to 
challenge narcissism in the workplace with what the author* termed 'sustainability'. He listed the qualities that can enable an effective challenge and disruption to narcissism. Reading it made me laugh as I recognised that I had few of those qualities, particularly the ability to tolerate frustration and anxiety. But it gave me things to work on. Food for thought. Trevor Noah** did something of the same in a clip from his show about how to fight with a toddler (you don't - you ask them to elaborate, rather than telling them they are wrong) as a lesson in how the media should respond to Trump.

*Gregory, Bruce. July 23 2010.'The Impact of Narcissism on Leadership and Sustainability'

$<$ http://poisonfornarcissist.blogspot.co.uk/2010/07/impact-of-narcissism-onleadership-and_23.html\&gt; "Recognizing the presence of narcissistic forces is an important aspect of the transformational process. Moving to the next phase, interacting effectively with narcissistic forces, involves a number of important factors which include: awareness of and freedom from victim complexes, freedom from being intimidated, skills to deal with intimidation efforts, excellent emotional boundaries, accountability skills, skills for building consensus with others in the group, empowering others, and a highly developed inner ability to tolerate frustration and anxiety." **https://youtu.be/9P1IVQJdVvE

\section{[yesterday, exchange with S]}

I'm re-reading your blog and I'm wondering, what is wrong with narcissism? Why has it got such a bad rap? Are we not called on to defend our selves, our positions? To make a difference, to leave something behind, is this not good? Does it not serve a greater good? There comes a point where this is irreducible to the kind of normotic phantasies that you discuss in your work (and with which I agree, you've persuaded me). Can't there by ab-normotic desires? I don't know Bollas on this.

Hi S,

I love the idea of ab-normotic politics, phantasies, claims. What a wonderful turn on bollas. I might want to take this up later in a blog, including your question about narcissism. It's a fair question. And yes, narcissism is necessary otherise we repudiate and neglect ourselves. ...I was thinking not about healthy narcissism, but the overweening, mawkish, solipsistic kind. I worry about that because I 
am only engaged in the world in such a limited way.

Briefly (morning for you, late night for me - throwing a night-time log on the fire and heading to bed), yes, well, narcissism. Freud (from terrible memory) has primary narcissism and secondary narcissism. The primary is the refusal of the infant to recognize the breast as belonging to anyone else. "I am the world," I think he says. Think of Trump! That pussy is HIS to grope! Vile piece of filth. Never. The failure of even the most basic socialization. But secondary narcissism, or even tertiary (?), socialization turned on itself. Can there be a return that is not simply a repetition? And under what conditions? Your demands on the British NHS are not narcissistic, for instance, not in the least. Though they might unfairly, cruelly, be dismissed as such. It's where the seeming narcissist's demands yield to basic dignity, rights, community.

NOVEMBER 30, 2016 • 10:05 AM

\section{goodbyes}

I realised today that I must ensure Ive saved this blog in some other format, including printed out, so it won't be suddenly lost. I don't know why I think its important. Yesterday when A was trying to stretch and break up the fibrotic impasse of my locked knees, he asked me how many books I'd published. Seven, I said. That's good he said. It's good to leave something behind. It made me tearful. But then everything does these days. And that is, in fact, how I feel. Impelled to leave something behind, an imprint, an imprimatur, a hauntological artefact. To say I was here. And that it made some difference. Romantic narcissism, I can see that. But it is a deep feeling too and I can't repudiate it with criticism or scorn, or even simple self awareness.

$\mathrm{S}$ told me that Carlton University was attacked by ransomeware so the entire University system is now hostage. People's work, records, everything. I found local reportage on it, but nothing international. G's theory about this being the dark ages, all records on the verge of being wiped out, or just lost as formats replace formats. No monuments, no history. Just an end of times, even as we all make our ways through it daily, link ourselves up, create our information bubbles, obsessively record, worry about the impossibility of erasing 
records. And yet there it is. Only one of the awful paradoxes of our time. What can we call it. What comes after post-modernity. Neofeudalism, I suggested once to S. A conglomerated corporate version, a media regime. A rule of billionaires who live nowhere, and everywhere. Government serving a brand. Trumps modus operandi as everyone can see, but capitulation is the metier and miss en scene of this next era.

\section{[From my letter to $\mathrm{S}$ this morning]}

On goodbyes. I don't know. I feel the same as you. I want to hold to people I care about forever. I don't want to say goodbye to myself either, but I guess I'm past the point where it matters what I want. Or rather where what I want can be realised. I have stopped wanting those things, or many of them at any rate. I just want some respite. To be more comfortable. There is an inevitability I don't have the energy to fight or question or even lament. Much of the time I just wish it was done. To go to sleep and not wake up so I could stop suffering and stop being afraid. Yet that doesn't seem on the cards for me. So I registered a DNR. I asked $G$ that if I went into unsconsciousness, to let me stay there, spare me coming back to more suffering. I know it's upsetting to say this, and hard on him and anyone else I say it to. But sometimes it's kinder to just let people go. My mom and brother are planning to come over to visit the second week of January. But I find myself hoping I won't still be here then. A, my physio thinks I will be, as does $M$ the palliative care team member who visits. The district nurse thinks I'm on the way out for real now. I can't tell. A my oncologist, when I asked her, said that I would be able to tell, when it was happening. But who knows.

I think we all have to live in the indefinite conversation. What else is there? It makes time easier to bear. And it's part of what is hopeful about life, and politics too.

Love and hugs,

Xxxdeborah

NOVEMBER 29, 2016 · 3:12 PM

\section{advanced directive}

Many visits today, but not much help on the horizon. The district 
nurse clearly thinks Im in an $\mathrm{n}$ stage, so wanted me to fill out a form for ends of life care. A disagrees. Why, I asked him. I don't know he said. A feeling.

I requested a DNR form from the GP when he came to take a culture of my mouth and throat as I clearly still have a candida infection and am possibly not on the right drug. That was somewhat of a fight, but $\mathrm{G}$ was insistent on the phone, then they insisted on talking to me. But at least that was done. And at least they did come to do that. The palliative consultant rang and put the ixnay on sativex. She said she was involved in the original trials for cancer patients and in her view, and the trial showed, it had serious unpleasant side effects with little or no benefit. I think she would have prescribed it if I had insisted. But whats the point if she thinks it will just make my life harder. I think she does understand my problems with drugs. She has prescribed pregabilin at a half dose. To take at night. But I can go off it if it affects my cognition.

I gave in and read the papers today, even though the surreality of the news is like treading a nightmare. One story, about a Trump supporter who menaced a plane full of passengers, asking if there were any Hilary Bitches aboard. I wish I'd been there. Yes I would have said. Ugly Hilary Bitch right over here. And faced the asshole head on. The report said Delta apologised to passengers for allowing the man to continue flying, and returned their fares and banned the man from flying with them again. I suppose if Id been there living out my resistance fantasy, I might have been banned too. Maybe not. Maybe the full shock to the earth's axis hasn't sunk fully in yet.

So I'm tired. I did manage part of a supervision even though my voice is gone. And I took Chair's Action on a proposal for GFSS. $\mathrm{i}$ downloaded another book. But not sure I feel like reading it today. I managed some soup and $\mathrm{G}$ sou cheffed my suggestion about how to make a good grilled cheese sandwich - of which I managed a bite. I have to be careful and think about what I'm doing so as not to choke. But at least this is normal food. I wish they sold cool whip here. I could mix it with jello and tinned fruit like my mom makes. That would be nice to eat. Strange the things you end up wanting in extremis. 
NOVEMBER 28, $2016 \cdot 12: 37$ PM

\section{entr' acte}

I've started coughing up blood. Maybe from the coughing. Maybe from my lungs. I don't know. I feel more dreadful than I could have imagined. Why does this keep going? Something Polly used to say. Why can't it just stop. I'm done. It took me some time before I was able to really listen to her when she said that. I didn't see my own near future when I finally did listen. Its better if its fast. Not this malingering tortuous hateful decline.

Lola stares at me from across the sofa. I keep pushing her away because she wants to sit on me and it is uncomfortable. I'm sorry Lola.

So she stares at me. Sometimes smiling in her doggy way. Sometimes worried with her ears back. I look back at her. I'm sorry I can't do anything for her anymore.

Rereading Vida. This edition with a preface by Merge Piercy reflecting on the book. It is an apt portrait of recent history, and an insightful rendering of personal and political. It also concerns a time of war. I was a child then, the music of my growing up. It was beautiful and hopeful to me. The danger and the struggles were outside any reference point for me. Just the ideas of justice, and rights and progress in circulation, that resonated with me. So the book is an important intimate history of the times, for some of the people who took those risks, lost heart, lost all. Some I imagine, if they are still alive, are fugitives still. What must they make of Trump and the utter backlash against every gain so hard won, that he represents and the dark future he imminently heralds?

Visits from palliative care and district nurses. They wish they can help. I can see that. 


\section{what to do}

I have multiple doctors who watched my hands turn into agonising claws and I guess they felt sorry, but also have left it at half guesses and have yet to treat it as an emergency. So now I have lost the use of most of my fingers, and my hands are in constant pain and continue still to fold in and get further destroyed. They watched my knees freeze into a bent position so i can't walk, and I guess they thought what a shame, that looks difficult. But they haven't seemed fussed to find out fast what was going on, before my knees locked forever, too late for any intervention. I've had that for 8 months. Still no one seems to think its urgent to get them released. Some guesses and shrugged shoulders. They feel bad for me I'm sure. But my follow up appointments are months apart. They have seen my hip muscles freeze into a painful bend for almost 2 years. But were concerned with the lesions, not what was stopping me from moving. Or how to release them. I am still waiting for a pain clinic appointment. Now at least a year. They see me choke on water, and order a swallow test, which I'm supposed to get some time or other. I'm to wait for a call, even though i can't drink and that is happening now and has been for going on two weeks. They know i can't take opioids, and at times they are annoyed, at others sorry. I asked for sativex, but have heard nothing for weeks now. Even though i am in pain $100 \%$ of the time. They nurses are worried about pressure sores, but the air cushion they gave me is agony. $i$ can only sit on it for less than a hour at a time. They ordered a cream, but it hasn't come. That was a week ago. Thats all there is they say.

So what are the reasons for the slowness of things? Is it denial? Overwork. Foiled by not understanding with no spare time or feeling to offer. Shrinking services. Expanding populations. Do these make a difference when one thinks about anger and action? D wrote to me about Freud's concept of negative hallucination. The art of not recognising, as she explained, people who are present. She was talking about Trump politics. But maybe it applies here too. Not the art, I think, so much as the defence, the impatience, the weary resignation of not seeing who is present. So you can get on with your normal hands and your pain free morning routines. Do the things people do - walk, talk, eat, drink, brush their hair and their teeth, 
cook their food. throw a ball, sew or type or some other fine dextrous activity. I am aware of people's hands and i have stopped remembering what it is like to have them myself.

I've been watching youtube videos of food critics in LA, Chicago, NY mainly. Testing out eateries around the city. I guess I'm doing this partly vicariously since I can't really eat anything anymore. But also I like the showcase of what immigration brings - wonderful food. All of the business owners talked about love and their communities and extending family, roots, memories, comfort, childhood. I am also kind of shocked at the amount of food places serve in the USA. I've always thought of myself as a fairly big eater, but even in the year of eating cake, i never put away as much food as I see served up in these videos. Every sandwich has butter, mayonnaise mixtures, barbecue sauce, six slices of cheese. multiple piles of meats, like five meals smashed into one pile. And then side orders and milkshakes or beers. I wonder how people can eat so much without getting sick. I've always mostly shut down if there is too much food. Giant buffets. Big platters. So I don't know how people do it. I don't know if I could bring myself to try what is on view here, even if I could eat.

I now know of restaurants and food trucks all over Chicago. Does this mean anything.

NOVEMBER 25, $2016 \cdot 1: 45$ PM

\section{sick note}

Impossible to take sick leave. i knew it would be when I requested the note. People can't accommodate it. The need to recover. No space. And I feel uncomfortable about pushing it. Even with my voice gone again. The medialisation only lasted a couple months instead of a year. Choking on everything. Coughing at the stabbing itch in my larynx. I am always thirsty. Yet can't drink without choking. But one student pre viva and another about to submit and several amid the early stages. Can't leave this alone.

It's difficult to tell people the truth sometimes. That you are betrayed by their electoral choices, for example. Or that you don't want to stay 
around for the destruction of the world. Or that you have come to the end of hope. A said that to me today, you have to keep pushing, keep hoping, Why I said?

$\mathrm{G}$ has been talking about the imminent dangers to the free press. His analogy with the fear that makes people cooperate with serial killers or rapists who promise not to kill you if you do what they say. It resonates. What $\mathrm{G}$ is saying. But there is something more. The excitement many feel at the prospect of a scorched earth. They find it entertaining to entertain such prospects, even as they might gesture towards denial. They are avid for the destruction of others. They think it doesn't matter to them. Like watching a bomb drop on television footage. Beaudrillard's hyperreality theory. It is not a meta phenomenon this. It is a base thing, that many people feel, that anchors them to their sense of entitlement or sense that they are exempt. They get on with things, pretending that it isn't real. But in their assertion and avidity, they demonstrate how very real this is.

Alice Miller tried to psychoanalyse the fascist mindset, its inner life, its unconscious. I remember reading her work many years ago. I'll have to dig it out again. To see if it is persuasive, or more, provides a foothold for the converse, for the struggles ahead. I suspect that everything will have change. The music. The films. The books. The conversations.

NOVEMBER 23, $2016 \cdot 6: 57$ AM

\section{Accommodations}

Why is it done? Why isn't there a line of media that says, if you don't win the popular vote, you shouldn't win the election. I am sick of the accommodations here. And why have large media outlets met with Trump to be told off? What? Why don't they just tell him he is a pathetic cry baby and to grow up. You don't get to control what people say to or about you you infantile loser. You wanted to run for public office, be a public figure, this is what you get. Why are they all going along? What is wrong with them.

As we watch from a distance and this man breaches every rule and convention and no one says anything. The accept him as unstoppable as if they have no power to stop him. Craven and self deluding. It makes me furious and disgusted. Religions flourish on the idea of 
shame. And here is what it should refer to - the shame and culpability and complacency witnessed in just this moment by people who think the are above it all, or not vulnerable and who don't give a shit about anyone's welfare. Just their own greed. Because the truth is, they want this. It appeals to them. You can see it in their wilful obtuseness. You can hear it in their strident emollient voices. They find it exciting. I hate them all, beyond what I had imagined was my capacity to hate, and to be disappointed.

An endless supply of tears it seems, but my mouth is too dry to swallow properly. As the destruction of my hands picks up pace again, I realised last night that I am done. No more drugs that trade off this for the evidence free possibility of stopping the cancer. It should be a time where you decide to just try to be comfortable. But the world has changed and comfort is not possible in this beginning of the end of all good things. Why should this be different for me.

$\mathrm{S}$ wrote me a note today and it made me cry. All these tears. Nearly every day starts like this. Sometimes just like this, where someone sends me their words and it comforts me. Thats what happens when kindness leaves the order of things. Its small precious remnants break your heart.

NOVEMBER 21, $2016 \cdot 3: 13$ PM

\section{broken glass}

I don't think there is anything more to say. Or I can't remember why I thought this was important. You wake up and it was not a dream. The world is turned around, and you can't turn it back. Alone, or in the many. This is the unimaginable. Maybe there is a hush outside before it happens as people clear the streets. Maybe there is the sound of thunder. I recall the sound of the tremors, earth roaring, windows blasted out, the foundation doesn't hold because it was never bolted in place. Just a pretence of structure, blown over in an ill wind. because its cheaper that way. And winds like this don't happen every day.

I am mixing metaphors. All the disasters come together. Including those I didn't go through. 
Watching the movie version of Hair - a hatchet job on an effective play. I saw it when I was twelve. And after, I listened to the Broadway soundtrack incessantly. Let the sunshine in. It moved me. It was a soundtrack that made sense to me then. Much of it is dated now and uncomfortable. But maybe there is a wheel or more there that will need reinventing in the same terms as the original.

Reading in the news about school children weeping in the aftermath of the election. They have much to weep for.

All the comedy seems off as well. Nothing funny anymore from this vantage point. True of many parts of the world, this one now too. Analogy to me. Suffering is everywhere. Now me too. Am I railing at the injustice of it? Or am I just too tired. Do I remember better times? Not so much. It's like all the talk has changed. The dreams make no sense, just pass the time and then jerk you awake with a start. The temperatures are all wrong. None of the muscles work right.The mess in your own house. It gets on top of you. Conversations are all pending a day that won't come. And still, it takes too damed long.

NOVEMBER 20, 2016 · 9:35 AM

\section{dry places}

I am trying to do this now because I am running out of steam. The new sofa looks nice, but is too hard for me to sit on. Or maybe everything is. I have tried to jury rig some softer cushions but it isn't working. I need something that distributes my weight, is very soft and doesn't push back. I don't know what that would look like. Something to prevent bed sores i suppose, but not sure where to look to order that. Its probably on amazon, but I haven't been able to find something that sounds right. Normally I'm good at searches. But coming up short on this.

My mouth is always dry. Another dead end for searching because it isn't clear why. But its very difficult to deal with.

All I can think of today is me and how bad I feel. It shuts out the world, which is also a dreadful place in so many ways, more now than before the election. The world is a more worthy place to contemplate. 
But I can't manage it today. And shut in with just me is not a nice place to be.

$\mathrm{R}$ and $\mathrm{L}$ are coming over today. But I'm not sure how I'll manage it. Just trying a different chair took me to pieces earlier. I'm getting to tired for people. G says I don't have to do anything; I don't have to be a host and everyone will understand. So the problem is me. I don't understand.

I found popsicle trays on line. I'm thinking we can make our own out of diluted juice. So they aren't too sweet. I've gone off sweet and salt, and food in general. And I'm starting not to care. I hope what GH said is right. I'll just get tired. And sleep a lot. And it won't hurt.

NOVEMBER 18, 2016 · 1:09 PM

\section{the strongest heart}

To repair the world is not just a normative injunction. I would advocate for a levinasian understanding, an affective stance, a feeling for the world, to heal it, to love, to open the heart and take good care of things. And to refuse its ugliness, to rise up against its tyrannies, to adamantly militate against its injustices, all of them. This is to feel for justice as the condition of seeking or doing justice. These things are relational and anchored in some kind of empathetic reality, or if not they are empty postures, tithing against the odds of comeuppance, or only for the ostensible good of selected people. Everyone, not being welcome.

This, among other things is a key motif or maybe raison d'être of the film Crimes and Misdemeanors. Where a craven, lying, adulterous murderer takes solace and self exoneration from his acts of observance, while his sister passionately exhorts the familial dinner table to remember history, to be obliged to justice, and to be worldly, not exceptionalist in one's self regard and evaluation. I've never been able to forget this film for this reason. Despite my disquiet about its director.

Watching the film of Evita again. For all its flaws a persuasive spectacle of the persuasions of dictators and populists. Ignorance and entitlement elevated, the fourth estate destroyed. The worse than 
empty lotteries of circuses, to distract from the absence of bread, or the depredations by elites in the self aggrandising rhetorics of reinstated nationalism.

In one of the youtube clips i watched yesterday, someone pointing out that no one asked trump what he actually thought was great about america, to at least fill out what he wanted 'again' about it. And there were Hilary, Michelle Obama and Bernie Sanders continually stating exactly that - America is already great and this is why...

I think about these things. But there is also the constant hacking cough. No one can say why. Maybe cancer pressing on a vital structure. If so, no treatment for that. I am still dreadfully ill following radiotherapy, though admittedly it comes and goes. And I get on with work during the hiatuses from nausea and fatigue. But my voice is gone again and typing is more arduous as my hands continue to degenerate. Some people are staying in contact. But it is harder to reach back. I realise it is time to be making last lists.

Watching the staged violence, thinking of the smallest of margins between now and tomorrow. The Assads, and Putins and Trumps. Some people get behind them. Yesterday in a youtube clip, I watched John Stewart counsel against thinking of Trump supporters as a monolith. I am not persuaded. The upshot - that nice people voted for Trump. So what? The vote itself was an endorsement. What is the point of being nice, if that is what you are prepared to do? Nice people followed Mussolini, and Hitler. Nice people got behind Thatcher's destruction of industries, of Unions. Nice people support UKIP. Nice people. Nice is defeated by all of these propositions.

In the film, armies on horseback beat crowds with truncheons. Tomorrow, 'good guys with guns', with their right to carry, will intimidate at will and there could be slaughter. There already has been, before it got its current figure head.

I am catastrophising. I am engaging in hyperbole. It is maudlin and overwrought. I can't think my way to alternatives as everything I watch for pleasure is suddenly tainted, or ominous, or out of date, or even horribly prophetic. Like the episode of Law and Order G and I watched last evening, with its focus on the fringe right, in a time where fringes were the only place in the public imaginary for groups like that. 
NOVEMBER 17, $2016 \cdot 1: 49$ PM

\section{war}

I am inclined to make a gross generalisation about the left and its relationship to war. A lost urgency; a distaste, a traumatic aversion, a learned avoidance. Whatever it is, I hear current words of appeasement or denial and I feel spiritually sick. The necessity of refighting battles already consigned to history is galling. I feel the fatigue of it. The incredulity. But there are times for war. To be pacific in the face of the end of security, rights, equality, justice, hope. That is not peace. This is not a time for refuge in established routines, or pat wisdoms that no longer relate to the reality of the world. And by the way, those established routines, at the least, were ugly compromises that pushed back the parameters of acceptability. We've been shrinking violets over years of violations, pretending that compliance will stave something off. But it didn't. Appeasement is a weakness, a stance of fear, and at times, it is a stance of complacency, or privilege, or the denial that comes with those. It is in this latter instance that a charge of elitism is valid. Some appeasements are not craven in this way. But some are. And this is one of those instances.

If I had been asked in some of my earlier incarnations, I would have said and assumed that I was a pacifist. But I realised a few years ago that I am not. I am inclined to insurgency in circumstances like this. An ugly 'fuck you bitch' shouted at me by a man who almost ran me down with his bike, called over his shoulder as he road away, eyes locking on mine. Something like a gorge rose up in me, a magnificent repudiation, and I stepped forward toward him and shouted 'come back here and say that to my face'. He was shocked and pedalled furiously away. I was shocked too. And it was a welcome thing, a better me. The one I want to get behind now. I absolutely meant it. G was upset with me at the time, asking me if I was trying to get him in a fight. No, I said, surprised. I was trying to get me into one. I tried to explain how magnificent it was to feel willing to do that, rather than shrink away, terrified, cowed, because I could get hurt or worse. I did also have an instinct that he would run away. He thought he was looking at an ugly bitch, without having the first idea about what one really looks like. Maybe I seemed crazy to him, unpredictable, dangerous because what did I know that he didn't? It is right to be an 
ugly bitch in many circumstances; Hilary's 'nasty women' resonated because this is the truth.

So I am now an insurgent grounded in my house, stuck much of the time with my own company, talking to memories or projections. I don't know what form insurgency should take. Is a chair one of the places where you can credibly cultivate that? But then there is a need for words too. I can only hope it does something. Trying to help remake (take back?) the world with only my two cents to offer.

NOVEMBER 16, 2016 • 12:28 PM

\section{dreading this}

The new sofa arrived today. It is very nice looking, though the seat feels too hard for me. So will have to find jury rigged solutions to ease pressure pain. I have had many occasions where I've said I have never felt worse than I do now. Because this is progressive, it is true each time. And I have never felt this dreadful before. I didn't even know it was possible to have so much wrong at one time and to be in permanent pain and decrepitude.

I am awaiting and unwanted call from cardiology to set up a procedure to drain the effusion around my heart. I am dreading this. Maybe it wouldn't be so bad if I didn't have so much more wrong with me at the same time. I don't know how I will get through it.

I'm trying to think of something in the world to talk about. But my collapse has taken over and I am too sick to talk about anything else. Trying to find things to escape into on video. But the escapist films are all predicated on a previous reality - democracy, opportunity, kindness, fun, women having agency, life being beautiful. The interstices of these conditions where a problem can be mainly just personal (though not always) and solved in the end with the better future. Happy endings. Romantic comedies. Formulaic and easy to swallow. I look for these. But from this vantage point, they belong to a shattered world. And there is no escaping that.

NOVEMBER 15, $2016 \cdot 3: 39$ PM

\section{this fight is on}


How does a fight start? How does one decide that it is time. How do we let go of the impulse to be polite, or accommodating, or intimidated, or cautious? How do we come to act against a system, where our positions are precarious, or as they are in some quarters, reviled, cast as pointless, or pathetic, or pampered. This is a very small skirmish in the scale of all the things wrong. It is a small piece of the world. But it is my world. It is our labour. It is one piece of justice. On faith, or in the admittedly grandiose hope at least, that the converse is also true: justice anywhere is hope for justice everywhere.

And indeed. As one of the loathsome trump team (David A Clarke Jr) has said - it is pitchfork and torches* time in America. But it will be our pitchforks and our torches. I feel this.

*(see Seth Myers. November 132016 'Donald Trump's First Moves as President: A Closer Look’ https://youtu.be/-dfUbiNOyDE)

\section{[what we sent tom Palsgrave today\}}

\section{Dear -}

We have now had a chance to review the contract in detail and taken some preliminary legal advice, and we must inform you that we are extremely surprised at the unprecedented overreach and disrespect for authors that its provisions represent. We will follow up with a more detailed, clause specific analysis. But for the moment we must inform you that in order to enter an agreement with Palgrave with respect to our work, we will expect the terms of the contract to be significantly revised, such that it represents a properly reciprocal rather than adhesion agreement, and such that it represents a fair exchange between ourselves and the publisher. We will look forward to further discussion with you about this.

All best,

Debbie and Deborah

NOVEMBER 15, 2016 • 2:16 PM

\section{a very bad day}

Another day at the hospital. This time cardiology. The plural effusion is bigger so I am trying to accept that I will have to have a 
pericardiocentesis, without anaesthesia. Another trauma. It is neverending. But I feel so dreadful, it has persuaded me. I can't drink without choking. I don't know what that is about. And I can't eat because it makes me sick. The doctor commented on how much weight I've lost. So it was a very bad day.

I am watching 9 to 5 again on my iPad. Just a week ago it was an artefact, a good but dated representation of gender and workplace politics; a dated comedic trope. Today it is not. As I try to avoid the news of Trump's cabinet reinstating just exactly that pre lean-in political spectacle. Except it is worse. White supremacist assertion reanimated. If I were well, I would be done with struggle. How can this be anything other than or less than a war at this point.

NOVEMBER 13, 2016 $\cdot 1: 07$ PM

\section{if not now}

People are calling and writing about the USA election in an aftermath of Brexit. Everyone is upset. We've had impromptu worried conversations with uber drivers to and from the hospital about it. My colleague $\mathrm{M}$ sent round a note to us proposing we consider a teach-in or some other suspension of normality to mark this moment, to use our skills to think it through with students. The response was mixed, tending toward the status quo, invoking tuition fees, student disappointment, curricula that are already looking at current politics. I was disappointed. If not now when, I want to ask. Shouldn't the world stop when the world ends?

But what can I say. I can't create this conversation or meaningfully support M's suggestion. I'm on the way out. What is it to me, one could ask.

NOVEMBER 12, $2016 \cdot 1: 25$ PM

\section{abstract}

I have left yesterdays post unfinished. Too all over the place. Not really what I wanted to say. What do I want to say? Since the election, I have felt stymied. Where to look, what to reflect on. All directions 
seem like dead ends. I know I am not the only one who feels this way. I am chafing because this broken sofa is so uncomfortable. The replacement comes on wednesday. So I might get some benefit from it. I had to guess about comfort. It looked nice on line.

\section{Dear----}

I apologise for the lateness of my reply. Unfortunately I had to have some urgent treatment and it knocked me back, so I've missed your abstract deadline. Below I have sketched out a proposed (unorthodox) paper, but I entirely understand if it is too late to consider it. And I am also happy to revise or work through my ideas further if it is not too late to consider my proposal.

With best wishes,

Deborah

ABSTRACT (I haven't come up with a title yet)

This paper will constitute a sequence of meditations on the subject of death, dying and social media/tion. Drawing directly from and addressing the questions set out in the call for papers for this special issue, the author will aim to springboard from her particular vantage point as a dying person who uses social media in a variety of ways, to consider the transforming ecologies of mourning and the place of dying in the emergent spaces of social media and virtual portals to bridge the personal and the political. In so doing, the paper will aim to work through key feminist political questions concerning bodily self sovereignty, the broader raced, classed and gendered cultural imaginary and the place of mourning in the analogy of the personal body in crisis and the myriad crises of the body politic at this significant and difficult cultural moment.

Particularly with the outcomes of Brexit and the Trump victory in the USA elections, this is a time of crisis and loss as the complex consensus of liberal democracy have broken down and neoliberal ethics and body affective practices are morphing into isolationist nationalisms, writ large, and the resurgence of movements against justice and equality.

Professor Deborah Lynn Steinberg

Chair GFSS

Department of Sociology 
University of Warwick

NOVEMBER 11, $2016 \cdot 8: 56$ AM

\section{down stream}

I spent some time this morning downloading videos to watch. Funny, easy films with happy endings. Like Julie and Julia which I am taking a short hiatus from watching to say something here. I want to get away from things. Pass time. I skipped most of the news. I can't stand to engage with it.

Lola keeps wanting to sit on me but I am too uncomfortable to accommodate her. So I keep having to push her away. It gets worse before it gets better (if it is going to get better, which is not a sure thing). But knowing that doesn't make it easier to deal with. I felt the bad effects set in last night. I hope they subside soon. I have to call the hospital and change my cardiology follow up. I can't stand to spend so much time going to and returning from hospital appointments. I want a break.

So I am, in any case, caught here not knowing what to write about. I think I've exhausted the subject of me. And I am exhausted before I start at the subject of the world.

I am tired. Things drift into my head to say or write, and then they fade. I have email exchanges about Trump and politics thinking they are consequential for me too. I plan out sequences or quotes to post here. But it is too hard to follow through. Or I forget what it was. Or it seems hackneyed or stale or lacking in authenticity when In come round to do it. I could say maybe its just the radiation effects. And I haven't started back on Letrizole, though I don't think it will be any more effective than before. I can imagine the cycle of fading then rallying. But how long can that go on. I was wanting a time when I could have some life again. But maybe its just sleep that I will get, if the palliation works.

NOVEMBER 9, 2016 · 10:28 AM

\section{ill winds}


It is difficult to settle down. What world is this? I have been largely preoccupied with my own personal losses and catastrophes. I've been less interested in the papers. I can't find myself in that immersion in daily media that has for some time been my main modus vivendi, even before my current deficits set in. But I have insight into the situation where too much is wrong to begin to work up a plan, or a vision, or a will to reconstruct. Or salvage. Times are such that it is too late. There is an analogy here, to the devastation of a body politic. I read an article in Slate or Salon today, I can't remember which and don't feel like looking it up - with apologies to the author. The article - what we need to do to fix this, was exhausting and depressing even before we try to begin. Yes I thought. But its too late now.

In 2007, when I was first diagnosed, my surgeon B set out the prescribed year that would follow. As I listened to her catalogue one catastrophic treatment after another and the damages and losses that would accrue to that, I felt myself sink into a blank exhaustion. Or was it just refusal. I said, what would happen if I didn't do anything? She was shocked, nonplussed. Well, she said, the tumour will grow and then it will spread and then you'll die. Yes, I said, but I can do everything you just laid out and have the same outcome. And so it has come to to pass. I am glad I refused what I did. At least I staved off the worst for a while. i just wish I had let myself enjoy it more. My body intact. My work. My days getting up and doing the normal day to day things people do when they get up. Sleep. Love. Funny things. Good tv. Visits home. Trips to Toronto. Making the house nice. Raising a puppy. Learning to box. Finishing my book.

I can't see redemption in any direction. What was the point of living just to arrive here, at the end of the world, and it's a bad end. I am horrified at people. The selfish, cruel whatever it is in people that they would even contemplate voting for such a terrible man. I am angry at the absurd unquestioned narrative that crystallised around Hilary Clinton. She was not a flawed candidate. She is and has been a good person, a dedicated public servant, a comsciencious and honest broker at everything she had done. The made up scandals, the empty accusations, the pathetic demonisations. I am worried about my family and my friends. What kind of life awaits K or T or S. I think of $\mathrm{K}$, who believes that possibilities are open to her. That she has a right to determine her own life, follow her passions, invent her future. And I am sorry for myself. Now I have no way home. 
[From my letter this morning to $S$.]

Hi S, I'm in a state of shock. I don't know what to do with myself. It's the end of America. The end of checks and balances in government, then end of the Supreme Court as a force for the protection of rights. I can't imagine what life is going to be like for girls and women, minorities, the disabled, the ill, the low earning and poor. It's a catastrophe for the USA and for the world. Love Deborah

NOVEMBER 9, 2016 • 6:32 AM

\section{despot}

After a sleepless night of anxiety, the news this morning is worse than I could have imagined. It is unbearable to read the papers. G and I are stunned. Its the end of many worlds today. I have been preoccupied with the ending of mine. An intermittent dream of coming home. This is how the Jewish refugees must have felt, those that escaped before it was too late, G said. As we are now realising that we can't go home.

I can't believe I have lived to see a history reviving itself to scorch the earth again. Or to witness the end of America, or to start the countdown of the loss of rights that will rampage as it has already begun, past the recidivisms that have already been festering, poisoning the world for the past many years now.

I was a true believer as a child. I believed completely that justice was inevitable, that the world would progress to expand rights and equalities, too slowly, but go there nonetheless. I believed that I was lucky to be born when I was, when we could learn marvellous things in school, and there was a rule of rights and law, and peaceful protest, and public safety nets, and there was democracy.

NOVEMBER 8, $2016 \cdot 3: 10$ PM

\section{counting down}

Watching the end of the world. I hope that is not what we are doing today. I haven't dreadsedan election this much before, even counting the third term Thatcher/Major years, or Reagan, or GW Bush.

Its been a hard day otherwise as well. People staring at me with 
distaste and shock. A waiting room full. I felt like spitting in each of their faces. I still do. A radiographer incredulous that my pain isn't being controlled, but incredulous at me. As if there has never been another patient in the history of patients who can't tolerate opioids. At least I managed to jury rig an arrangement of pillows so I could manage the taxi ride. It was hard on G. He is tired. But upstairs in class.

I am concerned as I am not really eating, even when I think I want something. Its hard to swallow. I don't want anything I used to like. I noticed today that Ive lost a lot of weight. I still look normal. And Ive been this thin before. But what if it doesn't stop here.

The papers say it is too close to call this election. How can that be? I am staggered at the narratives that have solidified around Hilary. How is she not an ideal candidate? When she damned well is. How can people in such numbers vote for Trump? A horrible human being. A waste of space. A dangerous narcissist with a dictator fantasy.Though he is not the only one. Theresa May in her ugly, low profile way wants the same and, indeed feels entitled. What is going on with the world?

[My letter today yo the Patient Advice Liaison University Hospitals Birmingham]

I am writing to complain about the interaction I just had with the radiotherapy bookings at the $Q E$ cancer centre.

I am a patient with advanced cancer and in excruciating pain from tumour growth encroaching on sacral nerve roots, and which has escalated progressively as I've already been waiting weeks for palliative RT. I am booked for a CT scan pending that therapy this morning. Both my partner and I phoned this morning to ask if I might be provided with additional assistance at the entrance of the cancer centre as I can no longer manage to walk or stand or sit in regular chairs. We requested that a porter might be available at the entrance just before my appointment to get me at the least into a wheel chair if not a stretcher so as to prevent my having to wait in pain or force myself to walk to chairs that cause me pain, while someone hunts down a wheel chair after I arrive.

I was told off in no uncertain terms by a woman (I am sorry I did not get her name). She offered that I should cancel my appointment 
or essentially just suck it up. There was no engagement with me about my particular needs or situation. I am not in pain to deliberately cause problems for the cancer centre. Nor can I wait any longer to get a move on with palliative RT. There is no pain free method for me to get to the hospital. I was just hoping for some basic compassion and assistance with my particular pain and mobility problems. Being spoken to as if that was outrageous and unreasonable and being essentially told to sod off is not ok. This is a cancer centre. Patients there have cancer and I suspect not infrequently vexing challenges VIS a VIS pain and mobility.

I would appreciate a call back to discuss this...

Sincerely

Professor Deborah Lynn Steinberg

[They wrote back and said they would phone me this afternoon]

[UPDATE, the next day - The PALS team and the Hospital have been responsive, kind and apologetic and $\mathrm{i}$ appreciate this. They said they would give me some additional assistance when I get to the hospital. And they will raise it as a team issue for discussion. I was able to say again that I am aware that staff and services are under enormous pressure, but that I hoped that a way will be found not to take that out on patients who are already traumatised by their medical situation. Anyway, the upshot is that they have been nice about this.]

[my letter to my oncologist]

$\mathrm{Hi}-$,

I'm just back from my CT scan where I was told my RT appointment will not be until next Monday.

Please can I urgently request that I am seen for RT as a matter or urgency this week. I am in such terrible pain, I don't know how I can endure another week of wait until the RT and then another week at least until I have any hope of relief. I am in much more pain than when I saw you last Friday.

I do understand that the RT equipment is chock a block booked and there is tremendous pressure already on the system with patients needing treatment. But I am in so much pain I can only beg to be seen sooner notwithstanding.

A second request, is that for my RT appointment, whenever it is, 
would you be able to ask if I can wait for my session in one of the beds around the corner from the waiting area? It is very painful for me to sit in a regular chair.

With thanks,

Deborah

[S/he wrote back and said they would try]

NOVEMBER 7, $2016 \cdot$ 8:59 AM

\section{back in time}

One of the rooms could go back in time. It was my thought the other night. How you could have the option to correct the bad turns in the road. Or just know enough to do things that would have a better consequence later on. I was trying to think this through but couldn't find very many of those to think it would make much difference. Voice and guitar or base, instead of piano. Yoga and Karate instead of gymnastics. Stay at Birkbeck and buy a small london flat, when it was still possible. Don't straighten my hair, but just let it be what it was. go to Berkeley first off. Work more summers. Be less worried or afraid of risk.

In my thoughts originally it was a whole scenario. Another avenue that might be interestingly tried out. But on the page, it is a cliche and I'm uninterested. . . I like the way station . I like the textures I invented. I like the way it feels to be there. It suggests a direction without being one. It feels like movement even if it doesn't mean going anywhere. I like resting places. This wait here is not restful.

I've been feeling sorry for myself. Its anger. I am angry. I am antagonistic and unpleasant. I have a reason for this.But so what.

NOVEMBER 5, $2016 \cdot 7: 42 \mathrm{AM}$

\section{fighting words}

I have to go to a hospital appointment in an hour and I am dreading the car ride as I am in so much pain, I don't know how I will endure the ride. It is like this every time. Waiting for an appointment that always comes far too late to do me any good and where I have to go 
through torture to manage it. If this had been done a few weeks ago, I would have been able to get there without agony.

We put in a chair lift on the stairs today. Another concession. But I'm tired and barely able to move. Another oral candida infection, just as awful as the first time around last March. I wish I could just stay home this afternoon and go back to bed. But I think I need palliative radiation and $\mathrm{A}$ wants me in clinic to evaluate it.

The hospital trip yesterday was as I thought not really crucial. We could have had the discussion by phone. But it's not A's fault. I should have said something. And also arranged for a CT scan yesterday. Now I'll have to endure this pain for a number of days and then make two separate trips to the hospital. Then another wait of a week at least until I get some pain relief. Its keeping $\mathrm{G}$ from sleep as well. This illness turns you into a horrible inconsiderate source of unrelenting strife and discomfort.. Maybe thats why people feel relief when someone like me finally dies. Its enough already. It ruins everything it touches. I am sure we are all tired of me.

M. from palliative care raised the question of marijuana and whether I would consider that for pain. Yes I said. But I don't know anyone who uses it and would have no idea where to get it. Its illegal in the UK in any case. L said something similar. I guess I could ask around. I am feeling pretty desperate.

NOVEMBER 3, $2016 \cdot$ 11:15 AM

\section{aside}

I don't think I will have time for the other places. They drifted into my head the other night. That I might rewrite Dante's Inferno. 9 circles. 9 doors. Something else possible. The beautiful things. It might be eerie, but it also has comforts, and places to sleep, and safety, and even small companions. Even if you are alone, it could be ok. Whichever door you choose. I am inspired by L's epic poem from all those years ago. Her idea at the time caused me worry. How would you know what door to choose. What if it was a mistake? But it could also be that all doors are good doors. And you don't have to choose. You can go back and forth. You can find your way out if need be. 
There might always be a port in the storm.

I am glad it occurred to me that I might build worlds that give me comfort. And that I can compose out of the beautiful things I care about.

NOVEMBER 3, 2016 • 8:56 AM

\section{bad tidings}

I had a panic attack last night. It lasted for hours and it was awful. I still am feeling very bad. It looks like someone will finally come today to take blood and I am trying to insist that it is evaluated as a matter of urgency. If it is hypercalcemia, I need to have this seen to. I am supposed to also get a doctor visit. I can ask to check for oral thrush again. As it might be that too. I haven't got an oncology appointment yet. How would I get there in any case, once it does come through?

In amidst is the horror spectacle of the US election. I dread a Trump outcome. Who are these awful people to whom he seems to speak, to move. I don't understand them. Their grievances, their sense of entitlement. It is our country, not just theirs. I can see there is no getting through. I've theorised it. But understanding it is not really understanding it.

There is no 'giving up'. It just gets beaten out of you. And it is long, drawn out, and worse by the hour.

NOVEMBER 1, $2016 \cdot 11: 48$ AM

\section{intermediary place}

When she woke up, or came to, or something that followed blankness. She found herself on a road glittering with octagonal settings, warm to the touch, clear of the snow that banked on both sides and up a short escarpment. She was wearing a favourite lightweight black ribbed knit pull-over with a high neck and long sleeves. Her overdress was also of black wool, knitted and falling in an a-line smocked style away from her body. The wool was luminescently black, absorbing light with a sheen. Her boots, to the knee were on a flat moulded sole, and made of black shearling. Warm to the knee, where a small lip opened and there was a long seamed detailing along the backs. She 
wore fine woven leggings, also black.Her loose coat, with fur lapels, was black shearling, lined also with fur, and with a fur-lined detachable hood. She wore cashmere lined gloves the length of gauntlets. She noted they had fingers. I guess my hands are alright after all she thought. She carried a duffle bag with the long strap across her body, that contained a change of clothes, some journey food, some loose coins, a wallet, several small soft figured animal replicas - love tokens she remembered, a notebook and a pen. A small bottle of water. Around her neck on a long gold chain, she wore two delicate rings, one with a clear topaz stone and the other with three small rough cut diamonds in a row. There was also a small medallion, enamelled orange on silver. A peace sign. On the back was the name Lola. Not her name. On her left wrist was her favourite turquoise strapped watch. Her scarf was long, knit of multiple wools, asymmetric, gold and black. With gold fringes. My mother made me this, she remembered.

The wind was freezing and she sank as far as she could into her soft coat and hood. Just across from where she stood there was an enormous,symmetrically wide, many storied building made of what looked like white stone, inset with six paned double fronted windows in casements that each ran floor to ceiling in height, with wrought iron decorative juliette balcony styled grilles across the front, rising a third of the way up. It was difficult to discern in the cold grey pearlised fog how high the building was. It had wide stairs leading up, grainy with what must be salt, against the icy cold. There was a grand covered portico, and stylised great double doors of wrought iron covered over with glass. a single pane both exterior and interior. There was a number fixed - 45. Maybe the doors were a French style? It was hard to remember. As she moved toward it she began to see the subtle veining of rose and silver and gold in the white stone. Some kind of marble.

It seemed like a public building, a hotel, she thought. A way station, it came to her. From where? She made her way to the doors, and entered to a great foyer, vaulted ceiling hung with glittering chandeliers. The expanse was furnished with clustered sets of deep sofas and comfortable chairs, beautiful matching ottomans, alongside glass coffee and end tables. Some of the sofas and chairs were upholstered in velvet, some in a thick tapestry style. None close to her were occupied, though there seemed to be people dotted here and 
there toward the other end of the grand reception. They seemed to be reading. Or sipping from steaming cups. Some were grouped or in pairs speaking quietly. One held up a paper map, regarding it with some intensity. There were plush rugs laid out to divide the space, covering a marble inlaid floor. There were columns, also marble. Onyx and rose, gold inlays, framing the reception desk. The floor gleamed like pearl, with the inlaid designs at the borders. Thassos marble, the name came back.

She went to the desk and the older man behind it, beautifully suited, offered her a key without comment. She was surprised, but not alarmed though she did not think she had been here before. She stood in place looking at the key, and its attached tag - also 45 . Your room is ready and just through that hallway, he said after a moment, pointing. How long did I book for she asked? As long as you want he said. There was a pause. We laid out food. We weren't sure what you might like. Enjoy, he said and smiled.

She looked at him, not really being able to make out his features. But then she had always had problems with facial recognition. Ok, she said. She walked across reception to a wide, plushly appointed hallway, Marble, gold inlaid mirrors. Creamy white walls. Along the hallway, by each door, there dotted frosted white glass uplights. There were occasional tables with glass bowls and vases. Apples in one bowl, foxglove sprays in a clear glass vase, sunflowers. And orchids. There were framed prints - Miro, she recognised, Lichtenstein, De Lempica.

She came to her room -45 , inserted the key and went inside. Next to the door was a closet for coats, a tray for boots and shoes. She removed her boots and put on the bootee slippers she found. She hung up her coat. Put her bag on the shelf along with her gloves and the scarf.. It was a suite styled room. The living room was at the centre. There was a deep anthracite velvet sofa in a partial chaise style so you could stretch your legs out facing two easy chairs in a contrasting cream crushed velvet. The ottoman was a great square, upholstered in a zebra pattern. There were plush cream decorative pillows and a warm cream wool throw. A set of coffee tables flanked the sofa and a narrow console table at the back held a tiffany lamp, a box of tissues in a lacquered cover, a set of three belleek ornaments, a latticed bowl, a small vase, a place card holder. The floors throughout, like the reception hall, were pearlised 
marble, layered with a large plush cream rug defining the living room. She knelt down. The tiles were warm.

Just off the living area, at one end, there was a small beautifully appointed black gloss kitchenette. With a two burner gas hob, a small oven. small cupboards holding pots and pans, bakeware. with drawers for silverware and spices below the worktop, open shelving above. The worktop was cream in some semiprecious stone, she recalled from a photograph she had saved, and seemed lit from within in a quiet, gold translucent glow. There was a Dualitt kettle and toaster on the worktop. The open black onyx shelves held several blue pottery mugs, a small set of white dishes and bowls, clear glasses, a set of nested glass mixing bowls, a small silver caffetiere next to a vacuum lipped blue porcelain coffee urn. There was a cream Kitchenmaid mixer.Various sized spatulas for cooking, and baking were standing upright, next to the hob, in porcelain containers, that may originally have been meant for something else at one time. There was a small beech knife block including a chef's knife, a paring knife and a slim all purpose knife as well as a set of kitchen scissors. There was a stainless steel sink, with a detachable tap, a small dishwasher and refrigerator set as drawers within the cupboards, another stainless steel drawer that turned out to be a freezer. There was a further tall, white doored cupboard at one end which, on opening contained a washer/dryer unit, a flower patterned broom and dustpan, red bucket and red handled mop, a lightweight rechargeable vacuum attached to a small charging station on the cupboard's back wall. At the other end, framing the kitchenette, and abutting the worktop there was a further tall and narrow cupboard which turned out to be a pantry, meticulously organised with canned goods, glass jars with raw ingredients, grains, raisins and what looked like cereal, sauces and mixes, boxed goods, bags of pasta, bread bin, and a few small appliances. At the far end of the kitchenette was a small tulip styled black glass dining table with two upholstered dining chairs tucked in. There were two further delicate folding chairs leaning on the wall. The kitchen contained a small black floor mat in front of the sink, and just to the side of the dining table, another mat, with a small stainless steel water bowl, next to a two empty, licked shiny glass bowls. Everything was spotlessly clean. Next to the second mat, a glass double glazed door led out onto a balcony. The furniture there was covered for the winter. At both ends and along its length, low raised beds were strewn with bark chip and small shrubs. There was 
no snow as it was protected by an awning above. But it looked too cold to go out. In the door itself was an inset small pet flap. The beds on the balcony, she figured might be for toiletting and then dashing quickly back in again to get warm. Get fed.

One wall of the living area, behind the sofa had floor to ceiling book shelves in glossy white, filled with books. A cursory glance revealed their organisation into categories. She could see the science fiction next to the crime novels. The titles were mostly familiar. Across on the other wall from the sofa, on a low console unit flanked by further glass fronted shelving, this time filled with decorative items in silver and coloured glass, was a large black screen.

The other half of the suite contained a large bedroom, with a dressing area, a desk area facing a widow, with a comfortable high backed desk chair. On the desk was a wide screen and translucent keyboard, a phone. Next to the office area was a small well appointed bathroom, complete with a glass mosaic tiled shower and a granite worktop over a white cupboard that held the under-mounted sink. The granite was oro stupendo. She knew the design. She had picked it out. The floor tiles were smoke black semi glossed slate. There was a large rectangular deco styled mirror over the sink and a small medicine and toiletries cabinet inset to one wall of the shower. There was also, behind a soft black velvet drapery, a set of black framed french doors in the crittal style, that opened on to the other end of the balcony.

The bed was tidy and invitingly made, with an upholstered ash-rose crushed velvet upholstered headboard mounted to the wall. It was king sized and fitted out with white cotton sheeting on the mattress, a white linen cover on what looked to be a down duvet. There were plain white cotton pillowcases on the pillows. A low ottoman at the end was upholstered in a familiar rose and dark red velvet tapestry pattern. Its lid lifted to contain a second set of sheets and a spare cover. A warm knit throw in cream with black fringes and black patterned detail. The rug was a deep plush pearl colour, wider than the bed. The mattress was soft, but held its shape well when she briefly sat on it.

A knock at the door. She answered to find another, younger man pushing a small cart. We weren't sure what you'd like, he said, but hopefully this array will do. Just dial 9 on the desk phone if you'd like to order something else. When you're done, you can push the cart into the hall and just let us know to pick it up. The gym at the basement 
level is open from 5 to midnight. And there is a small coffee bar in reception, as well as a shop for odds and ends if you'd like. It's also open from 5 to midnight. She went to her bag to get a tip for him, but he told her not to worry, she could take care of all that at the end of her stay.

After he left, she realised that again she had not properly seen his features, nor had gotten his name. There was a small pad of paper in the desk drawer and a pen. She took them out noted the transaction - first day, and his service, so she wouldn't forget later. Who he was could be reconstructed from the context. She wheeled the cart to the kitchen table and lifted various covered dishes. Too much food. One was a bowl from which there was a chicken-y smell. A clear broth with several soft dumplings. She took a spoon from the drawer and ate the soup. She poured herself soda water from a bottle she found in the refrigerator drawer. It was like what she remembered, though remembered from where? When she was done, she rinsed the bowl and laid it back on the cart and put the spoon and glass into the dishwasher. She pushed the cart back into the hall as the man had asked and then dialled 9 to let them know. She hoped the other leftover food would not go to waste and said as much. Perhaps it could be wrapped up and I'll finish it another time, she said.

Suddenly she was assailed with fatigue. She had thought she might pick out a book or watch a movie. But now she just wanted to sleep. She went into the dressing room and found it kitted out with the spare clothes she had brought with her, including a rose knitted long tunic which went over a deep midnight blue knit pull-over, spare leggings. Long knee sox in the stretch nylon and cotton mix that she preferred. But there were other clothes hanging there, and also folded neatly on the open shelves, that she hadn't brought with her. There was a narrow shoe closet. She was too tired to look through them now. There was an armoire which contained pyjamas in just a style she liked to wear. Soft, stretchy knit grey shorts and a light, white, one size too large, sleeveless t-shirt. She quickly changed. On the back of the bathroom door she found a plush terrycloth three quarter length robe in light grey. It looked like the one from home, though this one had a hood. She made a mental note of it and left it on the hook, heading straight to bed. She would see to her teeth and hair tomorrow. Meanwhile her hair, in a long plait, seemed tidy enough to last through the night. 
Once she got under the covers and was luxuriating in the soft comfort of it, she realised that her knees were straight and her hips like they used to be. Of course they must have been. How else could she have walked here? As she lay trying to remember, she heard a plaintive little whine from the floor next to her. A small brown dog with melting eyes and silky fur looked up to her with begging intent. Come up, she said patting the bed. The dog leapt up in a graceful arc and dived under the covers, laying itself against her back and sinking quickly into soft dog snores.

Another whine and this time a small fluffy white dog looked up at her. You too, she said. Come up. And she patted the bed. The white dog curled into the crook of her leg and torso. A small contented circle. She didn't think to wonder where they had come from. It was right that they were here. She settled in and for the first time for a long time, she went into a dreamless, deep sleep. It didn't matter where she or they came from. They were all here now.

It was a good place to wait. She didn't have a plan or a where next. The food was good. The room was warm and expansive. She apparently had resources. She was tired. And now she had these small companions. There was no hurry to leave. A voice in her head told her that many people decided to stay for such reasons. She could do that too. Or leave. Or leave and then come back.

OCTOBER 31, $2016 \cdot 4: 57$ PM

\section{adhesion}

$\mathrm{G}$ and I were just joking that we could produce a parody book contract for academics. In my thinking, it would arrive pre-signed in lieu of your signature. It could be from the Omnipotent publishing company. It would be take its or leave it set of provisions. And it would function in the same wording as any and all other companies, that remain in existence; they could be called Megalith and Associates, and World Rights Unlimited. One of the provisions can be that if you die all unpublished work along with your entire estate is forfeit to the publisher. Another could indenture your children to work on zero hours contracts in whatever capacity determined by the company and in perpetuity. Another would take guardianship of your pets. I'm embellishing now. But not by much. 
$\mathrm{S}$ read the email inviting me to sign and noted that it was odious. Preemptive, peremptory, entitled. My mother pointed out that this is what is known as an adhesion contract. This is a take it or leave it model of indenture. The offerer writes all the provisions, garners all the benefits. All obligations are arrogated to the signee. It also defines the status of a contract between unequals, under conditions of coercion.

OCTOBER 30, $2016 \cdot 1: 08$ PM

\section{numbers}

I just figured out how to check and found out that three people read this blog. I'm not sure that isn't worse than none. And I guess feeling that means I wish it was part of something, a conversation at large, a performance on a large stage. I know that the three who read it have dialogued with it as they have written or spoken to me about it. Why isn't that enough? G and I watch the star turns on Nashville and he frequently says "i wouldn't want that for myself'. "I would', I always reply. Not that I have ever done much to toot my own horn. It is a failing. Why, it didn't happen. When given choices, I always chose hiding.

A memory that comes back to me time and again. $\mathrm{G}$ and me in the Dupont kitchen. I am reading the biblical Numbers aloud and find it hysterically funny. I can see it as a play. God directing the catering, itemising the serving ware, the table cloths and the seating. Dictating to underlings. Obsessions with counting things.Peoples, cattle, coins. Whatever. Numbers captures all the ironic absurdities of religion. If it was seen that way, it could be a kind of fond teasing, to play it like that, or to point it out.

I am thinking about this in part because of G's essay on rabbinic authority and in part because of Tepper's Grass. The point of religious discourse and its relationship to power. Its jurisdictional functions through rhetoric. Maybe the transference I seek through a blog is just that kind of authoritiative standing. Some magic, some stardust, some claim on something, some self elevation, some inflation beyond my own horizons. 


\section{very small things}

The title of this entry owes to Sheri Tepper's Grass. A passage where the lead character speaks to god and learns of herself as a very small thing. A humorous god. An exchange that made me well up. She apologises for offending and God replies, 'you do not offend. I don't make things that offend me'. I'm not sure why that got me. The kindness of it. The lovely idea of God that comes in a concussed vision to her. $\mathrm{G}$ is writing about the folklore of the Judaic god. Or is it the scriptural version of folklore. With its petty God and self serving miracles, or sorcery, or magic. All.

I am rereading the book on the iPad as i can't turn book pages. I haven't read novels for a long while now. I filled that space with media immersion, emails, Skype meetings, watching box sets on video. But $J$ wrote and mentioned that Sheri Tepper had passed away recently. Like a blow, I feel the loss. Always checking to see, impatiently, for her most recent book. She was prolific, but not enough for my interests. All of my favourite authors are winding down or gone. Anyway, the arbai trilogy is an amazing read. I'm almost done with Grass. I'll read Raising the Stones again next. I was telling $\mathrm{G}$ he might like them for their meditations on patriarchal cultures and imperatives, religious fundamentalism and cultural relativism respectively.

I tried to use the leather sofa to lie down and spare myself the now agonising trek upstairs. But its no good, not comfortable, not easy or restful. So I conceded to $\mathrm{G}$ that we should order the hospital bed for the dining room. It upset me. Acknowledging something I want to refuse. Letting something in to sully the beautiful spaces of this house. I've tried to keep that ugliness out. But I'm tired. I need to lie down somewhere closer.

I am glad I'm done with the z pack today. I only took $2 \mathrm{mg}$ of the prednisolone so I am slightly less nauseous than yesterday. I've kept wanting respite, to feel well in body again, even if only for a while. To do ordinary things. To go to my office on campus - I haven't seen it since it was painted and repaired and a new carpet relaid - trying to make me more comfortable there. Someone has now put in a better easy chair, I've heard. I could put the poster art up that I ordered. I'd like to wear my clothes and travel under my own steam. Even though I know I will never drive again. I didn't even like driving. But I took it 
for granted and did it anyway. It was a means to an end. I'd go shopping in town. I miss shopping. I'd stop for espresso at the Coffee Republic around the corner from House of Fraser as it was the best coffee and the nicest place to sit. I liked its down at heel coffee bar atmosphere. Actually the best coffee was at Selfridges, on the third floor next to the posh clothes, bags and shoes. G wasn't that fond of it. But it had the thick grained espresso I used to like. And then I'd go home. I'd get minimally invasive palliative care and have my life back. I don't even care if I'd write again. I'd have the very small things back instead.

OCTOBER 29, 2016 · 3:44 PM

\section{breaking things down}

I don't understand what dying is. Even as my symptoms intensify and more and more goes wrong. Maybe it is some kind of denial, the incredulity I feel. I feel this sharp honed suffering. But not where it goes. I think it would be better if I did feel the end and stopped trying to imagine foods I used to eat or clothes I used to wear or buildings I could pretend to retrofit as if I could live there. What is the point of all that now. Or the fight with Palgrave, or my hands or the downward spiral of the NHS. Do I really need to care about Trump or Brexit or demagoguery. I wish I could go home. But it seems impossible now. Lacking realism. I tried to say that to my brother. But all I did was upset him, provoke a pep talk. I wish I could give him what he wants from me. I'm used to doing some things so I keep doing them. Maybe thats what this is.

Lola in her crate. I keep pushing her off my lap.

OCTOBER 29, 2016 · 9:05 AM

\section{disputations}

I've spent a good part of this morning trying various ways to access the contract from palgrave. Not only did they fail to send it to me directly, they are using an online document programme which prevents authors from printing out the contract or forwarding it. Essentially, making it impossible to take advice on the terms. Not 
only does this shock me, but I can see it is an escalation of the entitlements of publishers at the expense of authors. I am sick of this situation. I wrote and asked them to send me a hard copy, or failing that, the means to print out the contract terms so that I can review it in detail, without the implicit coercion of a site that demands a signature and at the same time makes it nigh impossible to interrogate, let alone negotiate terms. This document programme has no other purpose than coercion. It would be far simpler to send an email attachment. interestingly, unlike previous contract I have been asked to sign of late, this includes a pittance of consideration. Twenty pieces of silver against ourselves. A surety of self betrayal and the annihilation of our works. I am sick of this business model - which is in fact a stupid one, designed to not make money ultimately. A tax on academics, and then garbage.

I wonder now if $i$ have a pathological fracture in my arm and the pain in my shoulder is not a normal frozen shoulder, but encroaching cancer too. Ages ago i asked to have this scanned but it didn't happen. Like everything else, allowed to drift into catastrophe, until i am trapped in it with no remedy in sight. Just agony of endurance. As if there is a choice. The $\mathrm{z}$ pack is making me sick to my stomach. Or maybe the other drugs. Anyway, I can't concentrate.

Lola gave up asking to sit on my lap. She is demanding like that. But she gave up when I didn't respond. It hurts to have her sit there.

OCTOBER 28, 2016 • 11:49 AM

\section{broken bones}

A just sent over a text summarising my truly awful MRI report. He is sending a photo of it soon. I don't think I want to read it. It says what it feels though. Pain, from extensive disease and even a possible pathological fracture on the left. Though the left doesn't hurt. No hope. And no help. I am thinking I shouldn't tell my parents. Or even G. though he will read it here. The report is incomplete because they didn't get pictures of the right pelvis. I wonder if there is any point in doing more. The right is where it hurts the most.

D wrote to the publisher and is looking over our contract. The things I won't get to do. Books. And the deli in Los Angeles. And the Victoria Beckham denim dress I told $\mathrm{k}$ about, that I won't get to wear. Even 
this space is running out of space. Just a fragment. But I am so tired. Maybe its the flu. My last MRI was also very bad. But I think this one is worse. No getting around it. Is this the time when people start dispersals of goods and last communications?

OCTOBER 28, $2016 \cdot 9: 24$ AM

\section{passing time}

$\mathrm{G}$ is taking lola later to the vet to have her nails clipped. i don't like when she is out of the house. I worry something will happen to her. But she needs it done as her claws keep catching in the throw and she could tear one of them trying to escape.She doesn't like the laptop and has just gone to her crate. She doesn't seem to mind the iPad and will stay with me when I'm using it. i am just passing time now. i am going back to bed once the sheets are put on to it. Still too sick to sit here.

I have been having weird dreams. This morning while $\mathrm{G}$ was taking a walk, I dreamt that we were at a deli in los angeles and $\mathrm{i}$ asked him if he would split a tuna melt with me. When he came home, I told him about the dream and asked him if he even liked tuna melts. He said he does. Good, I said. Because the dream seemed very self serving to me. He said, didn't Freud say all dreams are self serving? I don't know. I don't think thats what he said. But I don't remember now. Freud on dreams was not something I paid much attention to.

I spent time this morning looking at the Marianos menu. I keep doing that. Looking at menus thinking that this might make me feel like eating.

OCTOBER 27, $2016 \cdot 12: 58$ PM

\section{Losing interest in food}

I've lost my appetite. I'm not sure why. i haven't lost weight so I will try not to worry about it too much. Maybe it's drugs making food taste off. today, maybe its the flu, making it hard to get anything down. I know its not a goos thing. And i both miss wanting to eat and am amazed in retrospect how much i did eat and it wasn't that long ago. G brought back food for lunch from Mariano's. Shepherd's pie. I keep 
going for odd things like that, that i never really used to eat or like. Earlier in the week I ordered Cheetos from Amazon. I thought about my mom's green bean and cream of mushroom soup casserole and her consomme rice. I called her to ask how to make them. Childhood foods. I picked at them then. So I don't know why I think I want them now.

It turns out its a very bad thing for cancer patients like me to get the flu.

OCTOBER 26, 2016 · 8:17 AM

\section{mens rea}

I watched Megan Kelly tell off Newt Gingrich on a youtube clip this morning. i felt like writing to thank her and to say I admired her composure and adroitness as she handled his screeching man-rage. Better her than me. I don't really understand her standpoint, how she relates to the conservatism she occupies in the public eye. i couldn't do it, even if i was paid a lot for it. There are some things money can't buy. Authenticity is one of them. Some things you have to occupy, to assert. Or at least I do.

I developed a cold yesterday. It came on after the interminable upright MRI appointment that I chose because I thought it would be less traumatic to do. But it took so long, I couldn't complete it as it was too painful. This was harder than being claustrophobic. The cold is making me feel even worse than it would have in the past. At least the vocal therapist rang me yesterday and told me to stop worrying about suffocating as that wouldn't happen. Even if the strangulated feeling in my throat keeps making me panic about it. This wasn't surprising advice as I already knew I was bringing this on myself. But as she was sympathetic, her advice was still reassuring.

So what is a guilty conscience or motive? And how is it relevant to the situation today. We can turn the question outward to the various demagogic wannabes who preach the line that resonates with so many - why should I pay for other people's problems? Why indeed. I tossed this over in my mind last night when I was trying to fall asleep. I don't know a rejoinder that might reach such a person. i don't understand the sentiment at all. Why wouldn't you want to pay in to a system that is there for everyone? I am ringside at the collapse of the 
NHS. Why do the people who want that collapse want it? Because it doesn't affect them one way or the other? But then why not shore it up. Meaning little argues for the ethical position. Ethical in the levinasian sense. The impetus or feeling to care for the other.

OCTOBER 24, $2016 \cdot 1: 38$ PM

\section{this is the way the world ends}

My mind couldn't settle last night. While I was not sleeping, it turned over and again like I did trying to find a position that didn't hurt. I found myself thinking that the (ts elliot) line was wrong.The world does not end with a whimper. It ends in conflagration, drowned at sea in the search for a haven, crawled up on banks of rock or sand or mud, with no prospects, holed up in bed with the drapes closed, racked with pain and hopelessness, in the crass bombast of a demagogue turned now on flesh to flesh out a terrible world. I couldn't settle because my hands hurt too much. And it hurt my hip to lie on my right and it hurt my shoulder to lie on my left. These are the only two positions available to me. it is an apt poetic fallacy of the wider worlds I inhabit, not my choices, but the choices. this all sounded better in my head last night than it does here, staled by having to reconstruct it.

People have been writing to me after reading things I put in this space. It is gratifying, but also makes me sad. Catalyst got back to me today to ask me to submit an abstract for the special issue. I didn't expect that. So I need to think on it now. What to propose. What I might be able to do. It was a nice letter. I'd like to think of something. Not this blog, but maybe some kind of sequential short essays on the topics they list. It might work. I'd have to hope I remember enough of what I already know to do it. I can't research as I did before. L and I are skyping tonight so maybe that will help me decide. She has done that for me before, letting me talk incessantly about my writer's block until i finally got past it, advising me against taking the job at UOIT. She was right; it would have been a bad move.

I'm going to give up on capitals as it is too hard to reach the shift key. and i don't feel like going back over everything to correct those mistakes. very ee cummings. it reads differently without the conventions of good grammar and punctuation. update: actually $i$ 
changed my mind. I've tried to do the corrections after all.

I just watched one of Michelle Obama's speeches for Hilary. Inspirational rhetorics of hope that resonate for me and i used to be involved that way. Calls to action, community, togetherness and mutual recognitions. It makes me think about how hope itself is framed and in turn frames or filters its own objects: better worlds. better prospects. better than this. and what we can achieve. Hope's normativity in this call to mutual arms and this visioning of some kind of justice, equality and love, is it reparative. or does it assert what can be repaired as its promise of what will be repaired? A faith based epistemology. and not clear what position it really occupies if one thinks about it through the lens of object relations. Is it an interesting transaction or transference or transubstantiation that is summoned and made in and through the rhetoric of hope? Does it refuse to mourn? i felt it too as I watched, even as i have personally parted with hope. Is it an analogous transactional space offered as the counter? - the gaping space for hate and self regard, for the feeling of entitlement - the standing in of this for actually being entitled. Or the standing in of the assertion of hope for its possible realisation. This latter feels real to me too.

$\mathrm{N}$ and $\mathrm{M}$ visited me earlier and we talked department politics and politics. It was a nice visit. It made me forget about my deficits. I recall my investments in that earlier life and I miss it. It is good to feel useful, even to feel put upon in some ways.

OCTOBER 23, $2016 \cdot 9: 57 \mathrm{AM}$

\section{companions}

Lola needs her nails cut. Two weeks ago i could still do it. but now my hands can't manage the crappy nail cutter i bought for her tiny nails. they are difficult even for good hands as they are tightly curved and black, so you can't see the quick. you just have to guess. Lola still trusts me. Even in this state. But I can't do it. And G will have to take her to the vet to get it done. another thing i can't do for her any longer.

$\mathrm{N}$ and $\mathrm{M}$ are coming to visit tomorrow. And $\mathrm{C}$ and $\mathrm{J}$ are coming today after my my Skype supervision at 2 and our Skype date with A and $\mathrm{ME}$ at 4. it sounds like a lot. it is in a way. The visits and kind 
companions checking in. If I was active, like normal, I could fill in the missing spaces. The ones that assert into the world and constitute your livelihood, your side interests, your jobs at hand that you do on your own.

I wanted to consolidate my phd pro formas into a booklet. M asked me if I would do this, as she seems to be curating my last presence in the world. I am bemused that she wants to do this. And grateful. Though I don't know if she sees it this way. So i started it before term began. A task that once would have absorbed me into my strongest comfort zone. And one I would have finished in a timely manner. But I haven't finished. My hands are so painful, I can't manage it. I used to think through my hands.It made me happy. There is volume upon volume to attest to it.

i don't understand what this is. this relentless undoing. its not even the cancer. something unimaginably worse. i never imagined it. I lived until March 2016 in a particular way. Then it started going wrong. Decrepitude, destruction, demise. Its worse than all of these.

This started as a post about companionship. But I am alone in this. Even though I'm not.

OCTOBER 23, 2016 · 7:37 AM

\section{singularity}

$\mathrm{S}$ wrote me this morning. having read this odd blog of mine. I'm still not sure what the point of it is. Maybe as a place I can write in brief bites, despite and through the constant battle with my hands. To make them hit the keys, then constantly correcting them when they do it wrong.

$\mathrm{S}$ wrote to me about mirrors.His thoughts were compelling. The double mirror to infinity. The single mirror to the walls we might erect between self and self. The strange abyss, into which we might watch ourselves fall, that might nonetheless be replete with something. i was very moved by this reflection on my reflections. i did always want to say meaningful things. I am concerned about being morose, self serving, trite. What stopped me from writing in this space in the first instance, and then stopped me from circulating it when I did start using it. G circulated it instead. A second hand 
second hand. It was nice of him to do this, to indulge my reticence and shrinking impulses.

L wrote to tell me about a special issue of Catalyst on dying and social media, among other themes. I wrote to the editors about the call for papers. I am pretty sure I can't manage a regular article. it takes too long to think. I can't manage windows. My books are inaccessible to me since my office upstairs became too far to walk to, it is too hard to sit in a chair, too difficult to get my hands to turn pages. How do you write without citation? How do you stay in conversations, when everything is conspiring to monologues, to solipsism, to mirrors only of one mind. I've always prized the dialogues of formal scholarship. How can it count, if I can only count on one vantage point? I argued in my gene book against monocultures and monoglossic perspectives. I argued that the preoccupation with singularities is a flaw of logic, a consoling mythology and a normotic projection. Its what I said at my book launch too, when I could still engage socially, in a public setting. I watched myself in my last public performance. I don't want it to be. But I am not like Stephen Hawking. I can't find a way to stay in the world, or to engage in complex theorising, or to stay connected to the larger conversation.

I have just come across your call for papers through a colleague ... I currently am doing some of what your issue abstract described, a dying person writing through a social media platform. The special issue is resonant for me, and in principle I would like to submit an abstract. I am not sure I am or will be well enough though to produce a conventional journal essay. So my question is whether there might be some latitude regarding style and form and if in principle you might also be interested in contributions that are not conventional, but that might nevertheless reflect on the themes you cite in the call for papers.

[from my email to the editors]

To L.

Thank you for the catalyst link. I just sent them an email asking if they would accept an abstract for a paper that I might not be well enough to write in the conventional journal manner. So we will see what they say. I'm not sure what I would produce. But clearly the themes in their call for papers are resonant. I'm not sure what I could do with them head on directly. But if they are interested, I 
could try to think of something. It's much more difficult for me to write as my hands are very painful and barely functional. It takes ages for me to type things out. And using multiple windows has gotten almost non- doable.

[from my email to $L$ ]

OCTOBER 21, $2016 \cdot 2: 34$ PM

\section{last edits}

I just watched the partially edited footage of my book launch which is up on youtube. I had the strange sensation of liking myself on film. Normally I hate my photographs. and indeed, I look pale and somewhat haggard in the footage. Though my hands are normal there, only a few months ago. It was mid June. And my hair looked nice. but the thing that I found myself improbably liking was how I came across, compromised voice and all. I seemed nice. And my comments were good. Well chosen words. Watchable. Its not what I expected. Or how I remember it exactly. I found myself thinking as I was watching it, what a shame she is on her way out.

OCTOBER 21, $2016 \cdot 8: 28 \mathrm{AM}$

\section{error message}

I asked A if she thought I was dying. She said no she didn't. Why, I asked. Because you would be feeling much worse, she said. So think about that. How things can be worse. This is not a new idea to me. It is just worse now, to consider it. Is that because it is now? Or because I am in such unutterably dreadful shape now, how can I endure a further deterioration?

I seem to be learning all over again how to type, this time with no hands, just single claws and I have to watch the keys. I have to go back again and again to make corrections. sometimes to correct autocorrect, because i am not looking at the screen and it makes edits without me knowing.

I am looking at the cut flowers on the mantle. They are not plants, or pets. They don't require care. just cut stems, a vase and toss them when they are done. But as I am no longer the one seeing to that, 
what do I have to say about it. They look nice. No thanks to me. This is denial. I won't imagine myself into the future like this. But then I stop imagining. Because I can't see anything else either.

OCTOBER 20, $2016 \cdot 4: 38$ PM

\section{self sovereignty - what do i mean}

$\mathrm{G}$ wants me to write this out in one place, definitively. But I seem to be bad at directed rants. I haven't been able to gather my thoughts on this very well so this is my third attempt. I deleted the earlier drafts.

I used the terminology of self sovereignty at the Feminist Classics Revisited talk. I don't remember how it came up. It was in the question and answer section. I was talking about women's reproductive rights and my history of activism. It came out spontaneously. one of those moments where I am in the moment and the thoughts just crystallise.

I used it again in my discussions with $\mathrm{M}$ about our introduction to the Body and Society special issue. We had a debate about it. A problematic concept. And yet what else is there that expresses ones right to determination over one's own body. The inalienable right over the disposition of one's own self and life, vis a vis someone else's interest, whether that is intrusion, or exploitation, or ownership, or life and death, medical treatment or not. What wards off the insistence that the pregnant body is a public body before it is your own, or not your own at all. What is the bulwark against the categorical devaluation of your citizenship in those circumstances, relegated to the status of a minor, or a slave. Even minors, in that capacity, progressively grow out of that prerogative of state or kinship, or the assertion of strangers. What of the biopolitics of life and death. The dying self who is understood to owe her life to other lives. What is the concept that shields against these grotesque abrogations against you. It is an imperfect one but it is one all the same.

and yet. What about people in the armed forces. Or employees and emotion work, or uniforms, or body searches and critical texts to intimidate them, make them walk faster, bend down, hold their bladders. There is no sovereignty there in ones bodily disposition. 
There are so many ways that people are conscripted, or demeaned.

Nevertheless. I put it in my advance directive. So this first and last wish of mine is not stolen from me. Sacrificed because someone is afraid, unequal to the situation, or because they feel you owe them the percentage points. Or because there aren't any decent alternatives. Even though its true, there aren't decent alternatives. Even then.

M from palliative care told me that she was concerned that one of my provisions in the directive is not legal in the UK. The one about terminal sedation. Yes I am aware of that, I told her. But it is what I wish for. The law is wrong. And I protest it. And it stays in.

Dear $M$,

...It's also probably why the self-sovereignty thing has resurged for me so powerfully. However problematic and compromised the concept is - it has re-emerged as my conceptual bulwark against the medicalisation of my life and the unwanted opinions of people who treat my condition like a permissive space (in this cancer is like pregnancy - both states in which you get recast as a public body, subject rightfully to other people's opinions, intrusions, moral estimations and unasked for advice). There have been so many conversations where I've had to clarify that as far as I'm concerned $-m y$ sovereignty over the disposition of my person is entirely and unequivocally mine. I claim absolute sovereignty over everything to do with my personal person. I do feel absolutely me - there are no blurred boundaries. Just yesterday I had to write to the lawyer about this so that my advance directive is actually directive - no medical personel gets to override my wishes for any reasons, in any context (or gets to override the wishes of whomever I designate to act on my behalf should I become unable to do so).

Anyway - its not that I don't entirely agree with the points you raised vis a vis my discussion of self sovereignty in the intro. Its that I feel both ways. And I know it keenly in this context - there is still the profound, pervasive political/pragmatic problem of other people's and multi-institutions' sense of right to the expropriation of your life whether on grounds of gender, or on grounds of cancer. So an absolutist language against that helps clarify my position. I do think it is a shame that the crazy Tea Partiers in the USA 
expropriated 'Don't Tread on Me'. I sometimes wonder if we can take it back!

(Excerpt from my email to $\mathrm{M}$ on completing our joint introduction, 2015]

OCTOBER 18, 2016 · 11:02 AM

\section{Bad Contracts}

I googled - 'how do you know if you are dying'. I can't tell if what I read is happening. Maybe not yet. I am tired and it feels bad. There is pain. I am tired of going to the hospital. Procedures that break you just that bit more. That you can't take back.

I am sleeping badly. D and I were just offered a book contract. The manuscript is due in October 2018. Is this meaningful still? I went over the terms set out in the email. Crap deals for academic authors. Off putting prices. Devalued work. A barely euphemised contract of exploitation. I used to be angry about this. No. I am still angry. I just don't have the energy to fight it. Or maybe I just can't compensate by loving the project. Too much is in the way of love.

I ask how I can write a book when I can no longer type properly. Or concentrate. It seems like a stupid fantasy. Or a lie.Why keep telling it.I used to want to write this book. I keep archiving and taking notes. Maybe that means I still want to. Is not letting go the same as affirmatively going for something?

I said and keep saying I don't believe that there is anything more. I told my parents, when they said I have to not lose hope that I have come to the end of hope. I upset them and I felt bad. But seriously. It is clear that that hope can't do anything for me now. Or maybe it can. I don't know. I no longer understand what hope is. Or remember what it feels like.

OCTOBER 17, $2016 \cdot 7: 52$ AM

\section{death as a journey}

I've never believed in any one thing or another about death. Assertions that death is a journey, or a better place, or a place at all - 
haven't been particularly persuasive to me. Maybe it is mawkish to think these things. I can't tell if I have some additional insight now. Or is it just the surfeit of bad nights where i don't sleep because I can't breath properly, or my hands are in pain. or my hips and knees are locked in their tortuous new normal.

I have been thinking about this off and on over the last weeks. The rituals in some cultures where the buried are sent with small gifts. Things they will need for a journey somewhere. Packets of food. Tokens of loved ones. Defenses to meet dangers. Writing implements. Gold for love, or status, or something arcane that can't be read across time zones. I told $\mathrm{G}$ that I want to be dressed in something I like. Something of the me that has been driven out, my distant memory. My clothes in the closet, waiting for a return. I would like a notebook and a pen. Tokens from loved ones. Some food. Something to keep warm. Something sensible to walk on, but still beautiful. Something with s heel, so the line is right. Someday, I would like Lola with me. I wish i could have her name tag so she can find me. I am afraid of being alone, where no one can. All of my other bad dreams are coming to pass. I think this one will too. Unless something is done. I don't know why I believe this. Or why there is some weird comfort in it. But let me take some things that mean something with me. Beautiful things that help you go on. The tokens that promise reunifications, or the means to sing or say, without choking or gasping for breath. Some reminder of what I did. When I was here.

OCTOBER 15, 2016 2 2:25 PM

\section{Small World}

How do you know if you are in the world or not. Is it when you do not feel like sleeping all the time. Is it when the news makes you feel like reading on or doing something. Is it when you think you might like to eat after all, or watch one of the shows you've been taping. Is it when you go to sleep, expecting to wake up again.

The headline today is that 'Theresa May lacks understanding about [the] seriousness of [the] NHS crisis' (The Guardian 15/10/16). If that was true, then she would have to be an unutterable idiot. But she does know. The point is that she and her government want it this way. I wish I had the unilateral ability curse her and her cronies with my life, 
as punishment, or a wake up call. Or as vindication. Even if there is no vindication. I've criticised the view that illness is retributive, or has any cosmic meaning. But I am angry. And it feels like an injustice. A malevolence or a deserved consequence for someone evil, or some evil. As I struggle with my hands and take ten times as long to write anything at all with hands that can't reach the keys any more. I read this headline and I only wish that the malevolence was mine to land where I will it to. To smite her. So her world and word was as small as mine.

OCTOBER 2, $2016 \cdot 6: 44$ PM

\section{Distances}

Someone travels and drags along their baggage. Or they get stuck somewhere overnight with a voucher for food and an unexpected bed. Or they are freed up. To feel normal. Like the day to day it used to be. When you'd leave the house, do things, come back, maybe relax upstairs with a book. Someone might have made dinner for you. Or had interesting things to tell you, the kind that get said and float away, not remarkable or memorable. Just the hum of things. Maybe they had to get up early and set the alarm for 5 , but the clock is 20 minutes ahead so they can use snooze to delay. It used to be the most irritating thing they did until it stopped. Well, maybe not the most. But it was annoying. You put up with it because it was so good to see them put themselves together and drive off for the day. Leaving to go into the world. Like people do. And then there were the things you always did. Small affections. Shows on tv. When they planned the groceries, and made all the food for the dog in a big industrial operation every couple of months. They liked to organise things. Like help you with packing, because they were good at folding and figuring out the best way to get everything to fit, without getting crushed in transit. They thought of things like snacks en route, or all the things to remember before getting out of the house for a big trip or getting the house tidied or done up. It was nice how they could look at a space and see it reconfigured in an instant.

Someone mentioned that to me today and I got angry. Or maybe I was already angry. 
OCTOBER 1, $2016 \cdot 9: 24 \mathrm{AM}$

\section{Tracy Flick and Guitars}

I've been asserting for the last little while that the media has been framing Hilary Clinton as Tracy Flick, the overambitious, amoral, overachieving object of the film Election. So i watched the film again yesterday with B just to representation-check myself and while there is much that seems resonant of the current USA election cycle and the contest of hateful tropes invoked by media reportage, I could see I may have been doing a doing a disservice to Hilary with this analogy. Tracy is not an adult in this film, however much her life is defined by ambition and political calculation, and even notwithstanding her own narrational self-assessment. Hilary on the other hand, is the adult in the room. And Hilary's is a record of public service, not selfservingness, dating back her entire career. In the film, it is clear that the dominant gaze frames Tracy as object of Mr McAllister's gaze she is, by his lights, a girl whose arrogance needs to be brought down, a manipulator who has gotten away with it for too long. Herein is the resonance with dominant reportage on the current election. While there is no Trump figure, exactly, in Election, there is clearly a Tracy figuration in the spectacle of the election. But watching again, a number of details have struck me that I hadn't recalled. Tracey as the object of her mother's love, possibly overambitious for her daughter, but also sympathetically portrayed. Tracy as the student whom the football hero-cum electoral competition Paul Metzler thinks is nice (though as audience we are supposed to know better and this is supposed to signify his naive sweetness by comparison). Tracy as the student who notwithstanding that everyone who knows her entirely understands her ambition, actually won the election because one more than half the students who voted, voted for her. Tracy as the student the other students basically liked, even if they weren't her friends. So Hilary is not Tracy Flick. But Election clearly presages their mutual figurations in the current public imaginary.

Off topic. I just ordered United Breaks Guitars, the Book off Amazon. Even as G is stuck in Newark, as his luggage was sent to Houston without him. Every year, United seems to separate him from his baggage. So as compensation, because it was a mechanical failure that grounded his second flight, they put him in a hotel and gave him a $\$ 10$ voucher for food. As it is early afternoon there and he can't fly 
again till tomorrow morning, I'm wondering how they expect him to be able purchase at least two meals worth of food for that, at the airport hotel no less, where captive buyers must pay a tariff on everything. So I re-sent him the Youtube songs (there are three) and that way found out that there is now a book (introduced by a song too). I'm delighted. The book is about social media and social movement - so it fits my project with D.E.. Serendipity. Watch tv and make it your life's work. What I did.

correction: Just spoke to G and it turns out that United gave him two vouchers for $\$ 10$, one for dinner (which almost covered the cost of a pasta dish from somewhere) and the other for breakfast, which might get him most of a coffee and porridge, but might not. He bought a yogurt at Newark yesterday for a snack and it cost $£ 6$. Anyway, apologies to United for the misrepresentation. And I heard that G's bag is having a very nice time in Houston.

correction again: the yogurt was $\$ 6$ not $£ 6$. A typo. Still pretty hefty a price for a single portion. And $G$ told me that the morning voucher bought him a coffee, oatmeal and walnut bread which is quite a reasonable breakfast - so thanks starbucks and apologies again, United.

SEPTEMBER 27, 2016 • 1:53 PM

\section{(Abandon) hope}

It has been a difficult week amid a difficult several months. I have to ponder on the point of hope as so many people have been telling me I must hold on to it. Maybe its a kind of transference or a kind of denial, hope as a transaction that spares someone of a loss or an unkind acknowledgement. I say unkind because my life has been full of kindnesses. Security, recognition, possibilities, love. Foreclosures are unkind. They obviate dignity, they steal from the poor, they wander off track without a map back or forward. Sometimes you can get by. I am not sure I will though. I am not made of the stuff of compromise or adjustment. I have limited patience. I don't want to change. As much as I hate uncertainty, I hate this more. The certain, already happened, cannot be fixed, demise of things. All except me. I am trapped in demise, but not going anywhere soon. 
SEPTEMBER 14, $2016 \cdot 8: 49$ AM

\section{Below the Line: 'A week with Trump: inside the campaign that keeps confounding'| US news | The Guardian}

\section{RESPONDING TO:}

https://www.theguardian.com/us-news/2016/sep/11/donald-trumpcampaign-ohio-fair-plane-media\#comment-83015407

There is nothing confounding about the success of Trumps campaign. The media has been preoccupied with him and articles like this give him free publicity and demonstrate the worst kind of disingenuousness. Why aren't you looking at Hilary Clinton's campaign, evaluating her history of public service and unprecedented experience for the job? Because the Trump train is your gravy train. The inequality of coverage and the investment in a useless, worthless demagogue who has a proven history of fraud, theft, hate policy and hate politics is what is confounding.

SEPTEMBER 14, $2016 \cdot 8: 46$ AM

\section{Below the Line:'NHS hospitals to cut costs by denying surgery to smokers and the obese' | Society | The Guardian}

RESPONDING TO:

https://www.theguardian.com/society/2016/sep/03/hospitals-tocut-costs-by-denying-surgery-to-smokers-and-the-obese\#comment82464179

The logic of denying treatment to smokers and people deemed obese goes against the underpinning ethos and point of the NHS. Aside 
from making little sense - why not exclude people who participate in risky sports, or drivers with a record of speeding or other moving violations. Or how about denying treatment to people with terminal conditions - it could be said they will die anyway so why waste the money? Take your pick. Life is risky. People have issues. And NHS treatment should not be parsed out on grounds of (some peoples) moral intolerance, body intolerance or preexisting medical problems.

SEPTEMBER 14, 2016 · 8:44 AM

\section{Below The Line: Trump}

RESPONDING TO ANOTHER COMMENTER:

https://www.theguardian.com/commentisfree/2016/aug/13/trumpclinton-election-chances-moderate-policies-economy\#comment81105262

I agree. This is a depressing article. But for me it is this identifier that caps it's over the top pessimism: “...the wife of the man..." Hilary Clinton cast as 'the wife of the man' in multiple insinuations, is both insulting and negating. The monied may be diverting to her, but that is not her reaching out as much as it is them reaching away from someone so lunatic and unpredictable, they can't support him. That she believes in working across the aisle might hamstring her policy objectives, but it is not in itself a sellout position. Nor is it true that she has repudiated the leftward platform of the convention, which contains goals that work explicitly against the failed neoliberal economics that have landed younger generations in hopeless spirals of educational debt, have targeted black Americans with a level of injustice and harm that recalls the days of Jim Crowe and that has cultivated a permissive space for violent incitement that encourages racist violence and even the rejection of facts and sanity themselves. Hilary Clinton represents hope for the resumption of an egalitarian and progressive political process and spectrum. And therein is an explicit place for Bernie Sanders and what he represents and has galvanised. 


\section{Below the Line: 'The appeal of torture: what I learned from teaching a class on terrorism' | US news | The Guardian}

\section{RESPONDING TO:}

https://www.theguardian.com/us-news/2016/jul/o8/tortureterrorism-college-class\#comment-78560447

This article demonstrates exactly why he should be teaching and why he is a good teacher. This is a thoughtful open minded examination of not only his own teaching practice but of difficult subject matter itself. Because the ethical question embedded in his rethinking of what he could have said to students - to get Them thinking - is 'what if you are wrong'? If 'justified' torture presupposes that this individual IS a terrorist and KNOWS information and that torture WILL produce the needed information, then 'what if you're wrong'? challenges the very foundation of such justifications. It is absolutely good teaching to raise difficult questions, to ask oneself as teacher and to ask ones students to enter into territory that refuses unexamined assumptions or unintended complacency

\section{Below the Line: languages of disability}

RESPONDING TO:

http://www.theguardian.com/society/2016/apr/06/paralympicscarly-tait-lifeline-car-disability-benefit-cuts\#comment-71912516

Around 11am-11:30ish

I appreciate the comments on this thread. But I'd like to suggest that the language typically used to describe disabled people is part of the problem. I know it is meant compassionately, but referring to disabled people as 'the most vulnerable' or 'weakest' members of 
society is an inadvertently damning, dismissive and inaccurate understanding. Disabled people have some of the most intractable obstacles, challenges and struggles. Engaging in these struggles is not a signifier of weakness. Some of the obstacles are gross social inequities of access to the means of full social participation and exercise of rights. Some accrue to bodily conditions themselves. Disabled people deserve acknowledgement and respect for our struggles and the extra we have to do to undertake what others may be extensively socially facilitated to do or just take for granted because they can. We are a group that faces increasing discrimination on top of these other challenges. I would like to entreat commenters here and sympathetic journalists and politicians to reconsider the terms of representation. Particularly as from a Tory standpoint, to be 'vulnerable' is to be legitimately held in contempt.

SEPTEMBER 14, $2016 \cdot 8: 33$ AM

\section{Below the Line}

Acting on a suggestion from my friend L yesterday, it occurred to me that I could try to make use of this erstwhile neglected semi-pointless blog space that no one knows about to include my below the line comments that I am frequently impelled to post in the reader comment section of Guardian articles. These are only snippets. They may make sense out of context. I have already posted a few earlier comments here, but why not make a thing of it.

Even as my world has been shrinking over the past two years essentially stuck on my sofa in front of an iPad - my interests have become embedded in a wider world of events past my own body, my field, my inner life. Some of this is technology. The iPad in particular has connected me up, enabled me to keep up with the varied responsibilities of my job, made me more visually orientated, enabled me to keep typing nearer the speed of thought even as my paraneoplastcally disabled hands have progressively lost the ability to manage on a regular keyboard. I am typing this out on my laptop and it is slow and error strewn because my fingers can't reach the keys properly and every little joint is inflamed and in pain. My more elaborated ode to the iPad appears in the introduction to my book because credit where due. 
The comments section of online news, or at least that section of the Guardian is a significant space for a number of reasons. First is that it is a more heterogenous, heteroglossic space (to reference Bakhtin) than one might expect. It is international, oppositional, contestatory, and inclusive of self selected readerships that are not necessarily centre or progressive left guardianistas. Second is the way that debates on particular issues often progress to exchanges of thoughtful, gleeful, sometimes borderline mean, amusing pedantry about what conforms or not to valid conversation, evidence, knowledge claiming, or indeed to guardian standards for below the line commentary itself. There are wonderful exchanges about rhetoric and reasoning and falacious argument. They are my personal favourites and reading them makes me glad to be alive and restores my hope for the world, even in the face of the unending cascade of bad news and badly filtered filters that fill out the news itself. Then there is the news, the tropes and rhetorics and tones of reportage and my own partisanities (i made this word up) provoked into speech - Tory policy on everything as it destroys democracy, education, the health service, the welfare and rights of the many, the social contract itself; political corruption, the gross spectacle of Trump and the obsequious avid media machine purveying him, media framing, media ethics, the fallacies of false equivalence, the shrinking state and the hate. A place for my skills to deploy in bites, in conversation in a public that is more public than the niche publics I usually engage either through my job, or through scholarship, or through my spontaneous rants to individuals on the telephone or via Skype or at gatherings (I sometimes used to go to gatherings).

AUGUST 25, $2016 \cdot$ 4:05 PM

\section{'Good Patient - Bad Patient: The Ethical Imaginary of Cancer' by Deborah Lynn Steinberg, in A Blum and SJ Murray (eds.). 2016. The Ethics of Care: Moral}




\section{Knowledge, Communication and the Ethics of Caregiving. Routledge}

GoodPatient:BadPatient.dls

JANUARY 11, $2016 \cdot 6: 10$ PM

\section{The death and mourning for David Bowie}

I was asked today if I would consider writing something about the death of David Bowie and about public mourning. This is awkward timing. The subject of mourning has become a vexed and maybe unwelcome one for me. Having collaborated some years ago to produce the book Mourning Diana, I have from time to time received requests to comment on the public response to the death of public figures, on the meanings of public modes of observance - the laying of flowers for example, and on the psychology of celebrity and fandom, that are at times galvanised into public spectacle and popular discourse. In these earlier contexts, I often talked about transference and projection - the ways in which the passing of public figures and their mourning could stand in for more personal losses, or create moments of unexpected catharsis and identification with those things about which we cannot bring ourselves to speak, when they are close and touch us personally. We live in a culture that repudiates death even as it is cultivated through public policy - austerity is nothing if not a harbinger of social excommunication and lonely death. In public conversation, death is frequently discussed as an existential wrong (no child should die of...), or as 'giving up', or as a 'lost battle'. Or perhaps it is not death that is repudiated, or not only death that is repudiated, but mourning - the accepting of loss, its empathetic identification, its non-heroic grievability - to draw inexactly on Judith Butler.

Of late, however, I have come to have a new vantage point on these questions. Like many others before and besides me, I have found a 
way to turn my own precarity into words and work, albeit in my case with a studied and distancing focus on culture rather than myself per $s e$, or my relationship personally to that precarity. My most recent article for example, concerns the public culture of cancer as deployed through advertising and the pervasive idiomatics of survival emblematised as a heroic figuration - the indefatiguable warrior of cancer survivalism. I see this as a cult, an insistent fantasy of the will - an offering, quid pro quo of willing life so as to have it. This is in distinction from the far less glamourous reality of those who survive it for a while, maybe for a long while, and of those who don't. I'm not sure which one of those I'll be personally.

My methodology for research has been immersive - I intensively embed myself in multiple media milieux in order to gain a larger insight about the rupture points and anxieties of the larger culture. I follow multiple trajectories and topics in the reportage arena for example - of which cancer is one of my designated topics. I collect, read and code every article about cancer that I find and that arrives via my personalised news-amalgamation apps. Strangely, this activity gives me distance from my own situation, even as it embeds me in its immediate context. I have found that I particularly like the Onion's diabolically funny and contrarian treatment of the cancer culture - I find it bracing. I have greatly enjoyed Erin Gloria Ryan's diatribes in Jezebel against 'pink crap'. I like Clive James' dilemma that he has outlived his own death - and how awkward this is. I think I enjoy these examples because they don't require me to mourn. Indeed, they assist me in the endeavour of not mourning. There is something about mourning that crosses a threshold, where one must re-imagine without oneself, as if it is me who dies, if I mourn a death.

On the terrain of dying, I have found myself bothered most by two sorts of article - First are those written either by doctors grieving their patients or family members grieving the loss of loved ones, or sometimes their own impending deaths. With these, I find myself in a strange transference - identifying with those left behind, not the dying or dead themselves. Second are those that announce the death of public figures - a litany of deaths, relatively young, or perhaps not so young, but so vital in the public imaginary, that their loss strikes harder. I've been collecting them, wondering sometimes if that makes me a bit unhinged. These are public losses - people whose art or influence or even just name recognition mean that their departures 
leave a sudden, palpable, recognisable empty space.

When Diana died so suddenly, even so prosaically, the drama both evoked and sustained what was experienced by a great many as a suddenly, shockingly evacuated space in the fabric of the public imaginary. That she was so young was only part of it. That she was so pervasive was the other part. Even more than that her idiosyncratic way of being had already catapulted her public persona into a place of mourning - lauded and repudiated - her evidenced, mourning of the precarity of others, and of the grievability of those 'othered' by exclusion or injustice. At the time, I theorised that this in particular attracted and generated the vox populi of personal loss. That for those who experienced it that way, this was a loss of not only a sympathetic public figure, but one who was spectacularly so. And as such, it was a death that both contained and exposed ineffable griefs and that made speakable, filtered in many instances through a language of political hope, a myriad of social grievances - the desire for a better society, for equality, for empathy, for common humanity.

The death of David Bowie - which reportage suggests was not sudden for him - was nevertheless sudden for us. A death that has followed on the immediate heels of a birthday album. The release of this album, with its attendant rave reviews, presaged his next incarnation, his most recent reinvention in a career of amazing reinventions, the veritable rennaisance of his person as much as of his art - it could not more forcefully have bespoken aliveness. And then, suddenly, we are told he is gone. Maybe it is that dramatically misaligned juxtaposition that wrenches apart both the imagined intimacies and the structural distances between artists and their fans, or artists and their fellow artists, or public figures and publics. Some of the public mourning comes from those who, themselves part of the public realm, have lost a collaborator, a fellow artist, a history of sound and spectacle that informed their own in some way. Some comes from the multiple layers of fandom, those who found intimately beloved the soundtrack of their earlier selves or present selves. And some comes from those, like me, who would not mourn ourselves if we could help it.

Deborah Lynn Steinberg January 112016

References

Clive James' columns in The Guardian at: 
$<$ http://www.theguardian.com/culture/clive-james\&gt;

Kear, Adrian and Deborah Lynn Steinberg (eds). 1999. Mourning Diana: Nation, Culture and the Performance of Grief. London.

Routledge

The Onion. 'Cancer Researchers: 'Don't Get Cancer'. November 18 2013. Vol. 49, Issue $47<$ http://www.theonion.com/article/cancerresearchers-dont-get-cancer-34599\&gt;

Ryan, Erin Gloria. 9/11/13. NFL Should Ditch the Pink Crap and Recognise Domestic Violence Instead. Jezebel. < http://jezebel.com/nfl-should-ditch-the-pink-crap-and-recognizedomestic-v-1633196427\&gt;

Steinberg, Deborah Lynn. September 2015. 'The Bad Patient: Estranged Subjects of the Cancer Culture' in Body and Society Special issue 'Estranged Bodies: Shifting Paradigms and the Biomedical Imaginary. M Shildrick and DL Steinberg guest eds. Vol 21(3) pp. 3-19

OCTOBER 11, 2015 • 9:27 AM

\section{Genes and the Bioimaginary: Science, Spectacle Culture - Review in The Guardian}
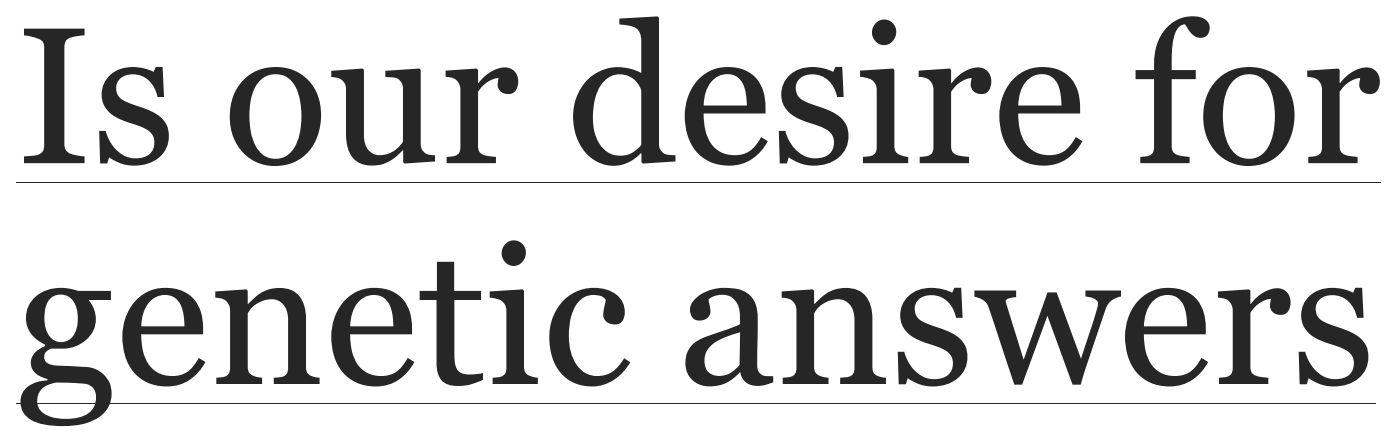
cultural rather 


\section{than scientific?}

Genes and the Bioimaginary: Science,

Spectacle, Culture, by Professor Deborah Lynn Steinberg, investigates whether the foundations of much genetic research are scientifically sound

\section{by Simon Copland}

\section{The Guardian}

\section{Thursday 27 August 2015 12.41 BST}

The last few decades have seen what some describe as a "genetic revolution". Advances in genetic science have seen genes become allencompassing in political and scientific discussion.

Do a quick survey of recent stories, for example, and you will find research that claims "intelligence, creativity and bipolar disorder may share underlying genetics" and a much-reported story that found that Holocaust survivors may have passed ontrauma to their children through their genes. Genetics has come to explain almost everything about our identities, whether it is our weight, our sexuality, or even if we are likely to become a criminal.

But is this based on sound science, or is it instead a cultural phenomenon using science to back it up? That is among the questions Professor Deborah Lynn Steinberg asks in her new book Genes and the Bioimginary.

Professor Steinberg, who researches gender, culture and media studies at the University of Warwick, has been studying the encounters between genes and culture for many years now. Steinberg began working on this issue over twenty years ago through an investigation into genetics, reproduction and the idea of "progress". In her latest book she has expanded on this to look at the genetic revolution as a whole. 
In Genes and the Bioimaginary, Steinberg investigates the crossover between genetic research and our society. Steinberg argues that "culture - including science - forms the context, locus and foundation of the search for genes." In other words, genetic science both shapes and is shaped by culture, or as Steinberg explained to me "the popular has infused the scientific even as the scientific has infused the popular".

What does this actually mean? Most scientists will tell you that science is "objective": science presents the facts and it is up to society to interpret these facts and decide how to use them. Steinberg argues, however, that it isn't as simple as that, particularly when it comes to genetics. Culture doesn't just define how we interpret the science, but influences the production of the science itself.

Steinberg uses a number of case studies to emphasise this fact. In one chapter, Trace: On Genes and Crime, Steinberg investigates the search for a "criminal gene". Steinberg examines the research that lead to the production of The Genetics of Criminal and Anti-Social Behaviour in the 1990s, a major symposium bringing together research on genetic criminology. The purpose of the symposium was simple: to investigate whether genes can influence our likelihood of engaging in criminal or anti-social behaviour. Researchers believed they found a positive correlation, one researcher stating that "genes are likely to influence the occurrence of criminal behaviour in a probabilistic manner by contributing to individual dispositions that make a given individual more or less likely to behave in a criminal manner".

It is here where Steinberg locates a problem. Put simply this research is trying to find a biological answer for what is inherently a cultural problem. "Crime" and "anti-social behaviour" are social constructs, which change depending on our society at the time. What is considered a crime in one decade may be considered normal behaviour the next, making a "biological answer" for crime very difficult to find indeed.

In fact Steinberg argues that much of the genetic research, criminological and other, follows from this false premise. In another chapter she looks at the search for the gay gene, which is again the search for a genetic cause for a socially constructed identity. In doing so, Steinberg argues that gay gene research, which argues homosexuality is passed down by mothers, is based on clichéd social 
assumptions. As she said to me:

"In many different respects the premises of the research were all embedded in pre-existing cultural stereotypes and ideas about gay men and about their relationships with their mothers. They were, in a way, tired tropes. What I was suggesting there is that it's science from a false premise. The underlying assumptions that organise doing that kind of research were already problematic.”

So why is it that scientists are engaging in this form of research? To understand this it's worth looking at another of Steinberg's case studies: the impact of genetic research on women.

In her first chapter Steinberg looks at the role genetic research has played in reproductive processes. In doing so she argues that by its nature this research is predominantly focused on the female body, both framing women's bodies as to blame for reproductive problems, and then implementing often intrusive procedures to solve the perceived problem. We can see this predominantly through the development of IVF capabilities, an intrusive and often painful medical procedure that only has an impact on women; a man's role may be active in other ways, but for them the process is not invasive in a bodily sense. Steinberg argues:

"The adversarial construction of the female body is heavily leveraged by the adversariality that pervades the 'culture wars' surrounding abortion and the larger questions of women's bodily sovereignty, reproductive rights and (de)legitimacy as citizens and social actors.

"In this context, the 'guilty' burden of genetic risk is, I would suggest, disproportionately weighted onto the female body, whose reproductive processes are already viewed with concern, if not opprobrium with dominant and legal discourse."

It is here that we can see the paradoxical role of genetic research in modern society. Genetics has been used both to enforce and upend our social norms and constructions. The best examples here are the search for the gay gene and genetic research involving women. While Steinberg expected gay gene research to result in a moral panic about homosexuality, for example, what she found was that it was met with more liberal responses - calls, for instance, that the gay gene should be used to promote gay rights. The moral panic arose instead about the possibility that women would abort pregnancies that might result in gay offspring. Indeed, genetic research prospects are frequently 
met with calls to ban abortion based on genetics, in turn enforcing control of female bodies through the restriction of abortion rights. These trends match our social response to these issues, with gay rights advancing across the Western World while abortion rights go backwards.

It is in this context that Steinberg argues that genetics has become a "spectacle". Genes have become all-encompassing, capturing our cultural and media imaginations in a way science often fails to do. Herein lies the problem, however. In capturing the imagination in this way the scientific debate is giving legitimacy to the cultural assumptions it is based upon - whether it is the existence of a criminal gene or the control of female bodies.

It is at this point that Steinberg comes up with a controversial, and extremely thought-provoking conclusion. At the end of the book Steinberg professes an "antipathy for genes" and a strong "desire to repudiate them". While she acknowledges the scientific reality of the existence of genes, she admits a wish this wasn't the case, a desire for us to reject the genetic revolution and all that it holds. As she argues:

"My disaffection for genes arises in part from the instabilities or illogic I perceive in the characterisation of genes as facts. But it is more than this; it is because the conditions of genes - the realities that produced the knowability of genes and that in turn, genes produce - disturb me."

Steinberg argues that the seductions of genetic research are based on the very things that genes can't explain. What makes genetic science attractive therefore lies partly in fantasies of mastery and control of human uncertainties: securing identity, preventing crime or illness, fostering desired capabilities, easing suffering, righting wrongs.

Steinberg not only questions the impacts of scientific research but the social conditions and cultural context that make it persuasive. In doing so she opens up fascinating discussions about not just the politics of science, but the purpose of it as a field. It is for this reason this book is worth reading.

GENES AND THE BIOIMAGINARY: SCIENCE, SPECTACLE, CULTURE, BY DEBORAH LYNN STEINBERG IS PUBLISHED BY ASHGATE

OCTOBER 11, 2015 · 9:18 AM 


\section{Why does the gun lobby claim rampant gun ownership is a social good?}

The latest mass shooting in the USA raises a great many issues, all of which are at this point, as Barack Obama has suggested, obscenely routine. Not only has the incidence of these events continued unabated, they have, indeed, escalated in frequency and fatalities. "From the point of view of an expat American who has lived in a country without gun violence as norm, it seems especially incomprehensible that even the most basic and rational limitations on gun ownership in the USA can't even be properly discussed.

"The statistics on gun violence cannot be accurately reported because hospitals and law enforcement either do not, or in some case are not permitted to, amass such data. Worse, perhaps, is the reification of the American conversation about guns and killing to the worst kinds of absurdity. For example, it seems virtually a requirement for holders of public office to state up front that they are in favour of the constitutional right to bear arms. Why should this to be so? Why is it possible to legislate for public safety with respect to collateral damage from cigarette smoking or unsafe cars, but not for collateral damage from guns?

"It is well known in the USA that countries with gun control have fewer incidents of gun violence. It seems incomprehensible that the gun lobby can deny this fact, with little challenge, and continue to assert as a social good, the unbridled ownership of guns.

Professor Deborah Lynn Steinberg is author of Genes and the Bioimaginary: Science Spectacle, Culture (Ashgate 2015)

An earlier version of this post appears

at: http://www2.warwick.ac.uk/newsandevents/expertcomment/why _does_the/

OCTOBER 11, 2015 • 9:15 AM

\section{Why does 'gay' need explaining?}


The 'gay gene' is an oddity that has resurged periodically in both scientific and popular media contexts since the original twins work by Dean Hamer in the early 9os. Hitting the news in a number of headlines is its latest incarnation - the 'gay epigene' - that is, the suggestion that gay identity can be epigenetically tracked and there inferred to have a biological basis.. See for example:

\section{http://news.sky.com/story/1566381/straight-or-gay-sexuality- linked-to-dna-claim}

\section{http://www.telegraph.co.uk/news/science/science- news/11919786/Homosexuality-may-be-triggered-by-environment- after-birth.html \\ http://www.latimes.com/science/sciencenow/la-sci-sn-genetic- homosexuality-nature-nurture-20151007-story.html ]}

Begging the question as to why a biology of 'gay' is a research objective in the first place - why does 'gay' need explaining when 'straight' does not? - it is worth exploring both the underlying logics of claims that 'gay' is biological and the typical narrative arc of stories which appear to give gravitas, if not evidence to support that claim. As noted across the reportage, the recent research (as Dean Hamer's did) focuses on a very small sample of twins who self identify as gay or straight. While it may be the case that the research demonstrated correlations in epigenetic markers (the interstitial 'switches' of expressed traits or tendencies), extrapolating from this to make generalisations about sexuality and identity would be a stretch even if the terms of reference - 'gay'; 'straight'; 'gene'; 'epigenetics' were unambiguous and singular. But they are not. What counts as 'gay' or 'straight' has been both understood to be and experienced as part of a spectrum of possibilities since the days of Kinsey. These understandings are considerably more nuanced and complex today. Sexual attraction and gender identifications are widely recognised to be neither neatly sutured together nor absolute. 'Gay' and 'straight' are cultural categories; subject to conflicting and changing cultural definitions. Epigenetics, moreover is the study of a dynamic of interaction of biologies, society and culture - all plural, all complex. One's epigentics can and do shift over time and in different contexts. Biology can be said to be as much an effect of culture as a preexisiting 'tendency' toward culture. A biology of 'gay', even in its latest 'epigenetic' incarnation seems a risible project. To claim either a 'genetics or an 'epigentics of gay' is essentially to claim that there is 
a relationship between a person's sense of identity and their biology - at best a tautological truism. Yes, stipulated, bodies and culture are not separate. But so what?

Deborah Lynn Steinberg is the author of Genes and the

Bioimaginary: Science, Spectacle Culture (Ashgate 2015).

An earlier version of this post appears

at: http://www2.warwick.ac.uk/newsandevents/expertcomment/ why_does_145gay146/

JULY 21, $2013 \cdot 10: 52$ AM

\section{An Open Letter to Lindy West}

Dear Lindy,

I would like to respond to your Jezebel article 'Melissa Etheridge Calls Angelina Jolie's Mastectomy a 'Fearful Choice'. (link provided below) At the end of your piece you ask 'if anyone can figure out a charitable interpretation of [Etheridge's statements], could you let me know?'

I would like to try.

Etheridge's comments did not strike me as incomprehensible or insensitive. Angelina Jolie is a public figure who not only knowingly made a public disclosure, but has been widely received (and put herself forward in her original NY Times article) as an edifying and inspirational subject. As a breast cancer patient myself, I can tell you that I entirely take Etheridge's point. While Jolie is entitled to make whatever medical decisions she feels are right for her, what those choices might be taken to signify for the rest of us should not be regarded as sacrosanct. Etheridge was not casting aspersions on Jolie's intelligence or fortitude, or attempting to make light of Jolie's ordeal. Rather her commentary offered an implicit critique of the moral capital that Jolie's response to her genetic diagnosis has garnered. Jolie's decision was at the least a disquieting one. It does not and should not provide an exemplar on which we should all model our responses to personal genetic diagnostic information (or for that matter to any of the clinical practices associated with genetics). As Etheridge suggests and as reality bears out, genes are not destiny. A diagnosis of BRCA 1 or 2 mutationdoes not guarantee that one will go on to get breast or ovarian cancer (nor in those who 
do get cancer, does it mean that it was a BRCA related one). And by sad corollary, a person could undergo a prophylactic double mastectomy and still get breast cancer. As Konnikova noted in her May 15 Salon article, the risk statistics associated with single gene 'flaws' refer to population patterns, not individuals. In my own case, with no family history of breast or ovarian cancer, my statistical risk, based on population patterns, was among the lowest. In the frame of my particular life however, the risk was $100 \%$.

In any case, how we deal with risk or fear of risk is not a straightforward proposition. Etheridge's states her belief that cancer has a holistic etiology - that is, she believes that the causes of cancer are complex and related to the whole organism and context. Your comment suggests either that this is a ridiculous belief or that it is a useless one because it doesn't suggest any sort of definitive action except airy-fairy quackery. While it is true that Etheridge may not have provided the most persuasive examples of what one might mean by that, and her understanding may or may not have been informed by emergent epigenetic and microbiomic turns in genetics, nevertheless a holistic understanding is certainly supported by these scientific developments. Epigenetics is the study of the complex factors that shape the expression of genes. Microbiomics is the study of the collective genomes of microbes $-90 \%$ of the human body, for example, is composed of microbes. Together these scientific turns cast considerable doubt on the validity and utility of single-gene led understandings of disease (especially complex conditions like cancer, which is not in any case a single disease) or single-gene frameworks for clinical practice. I would go further than Etheridge. It is my belief that our current paradigm entirely misunderstands cancer. I believe cancer is not only a normal part of living bodies (our body composition at all times includes cancer cells), but that cancer may turn out to be at the very heart of what constitutes being biologically alive. The notion that what produces life also produces disease or death is demonstrated in myriad contexts, including in the constellation of organisms that constitute human bodies, and which are not the outgrowth of 'human genes'. When in balance, this human microbiome is part of what keeps us alive and healthy; out of balance and those necessary microbes can become infections that can harm or kill us. And of course - life always and ultimately does produce death - since all of us die. Does my belief translate into definitive or effective preventive action? No, I don't think it does. But sadly, 
neither does Jolie's. Jolie's preventive double mastectomy has been framed (and she herself framed it that way) as a zero-sum choice that is, as a trade off of the loss of her breasts for the gain of her health. But there can be no such contract because cancer is a not a terrain of certainties. Is that not at least worthy of some disquiet? And perhaps some unquiet critical reflection?

Etheridge also believes that Jolie's decision is not a 'brave' (as in brave-in-quotes-and-italics) choice and she explains why. I agree. It is a dangerous thing to interpret someone's personal bravery (and I am not sure that 'bravery' is the right term for this situation) as an ideal type, or as a transaction that places their beliefs or actions categorically beyond critical evaluation. While Jolie has braved much, I do not see the choice of preventive double mastectomy as therefore and thereby not an act of fear, or therefore and thereby not an excessive or misguided response. Like Etheridge, I believe Jolie's choice is not an example at all for the rest of us. This is not simply for the reasons I outline above (and that Etheridge alludes to in the comments you quote). Many commentators have also pointed out that Jolie's personal wealth insulates her entirely from the gross inequities of health care that constrain the choices, availability and quality of care available to most Americans. Most American women could not afford or have access to Jolie's medical and cosmetic resources. Jolie herself noted this in her article and indeed, this issue informed the Supreme Court decision in Myriad to ban patents on natural genetic products, including BRCA genes. But perhaps more perniciously, Jolie's fetishised capital as 'the most beautiful woman in the world' is in my view no small part of her perceived bravery in this context. Had Jolie decided to have a double oophorectomy (which would have made as much sense according to the rational calculus of the choice she did make), I doubt that this would have been news. I suspect that it was specifically her willingness to sacrifice her breasts - (and then to have them almost perfectly reconstructed) that draws the applauditory gaze and adds the aura of unimpeachable moral capital to the excessive capital already associated with or wielded by Jolie.

I am concerned about constructions of 'bravery' that foreclose on uncomfortable questions, that shut down uncomfortable conversation, that rule out uncomfortable standpoints, that cast to the sidelines, uncomfortable people. My questions are uncomfortable 
to me as well (as I suspect Etheridge's were to her). I find it deeply uncomfortable to express doubt over the intimate medical decisions of another person, even as I am deeply uncomfortable by the rationalisation of those decisions because she is both a public figure and a vulnerable person. This is only one of the painful irreconcilables of Jolie's story for me. I think this may have been the point Etheridge was trying to make.

Yours sincerely, Deborah Lynn Steinberg.

References/links

Maria Konnikova's article: salon.com. May 15 2013. (Maria

Konnikova) Angelina Jolie, meet Nate Silver

http://www.salon.com/2013/05/15/angelina_jolie_meet_nate_silve $\mathrm{r} /$

Lindy West's article: http://jezebel.com/melissa-etheridge-callsangelina-jolies-mastectomy-a-513923168

- Angelina Jolie's article: http://www.nytimes.com/2013/05/14/opinion/my-medicalchoice.html? $\mathrm{r}=\mathrm{O}$ 